\title{
Orexin/Hypocretin and Histamine: Distinct Roles in the Control of Wakefulness Demonstrated Using Knock-Out Mouse Models
}

\author{
Christelle Anaclet, ${ }^{1,2}$ Régis Parmentier, ${ }^{1,2}$ Koliane Ouk, ${ }^{1,2}$ Gérard Guidon, ${ }^{1,2}$ Colette Buda, ${ }^{1,2}$ Jean-Pierre Sastre, ${ }^{1,2}$ \\ Hidéo Akaoka, ${ }^{3}$ Olga A. Sergeeva, ${ }^{4}$ Masashi Yanagisawa, ${ }^{5}$ Hiroshi Ohtsu, ${ }^{6}$ Patricia Franco, ${ }^{1,2}$ Helmut L. Haas, ${ }^{4}$ \\ and Jian-Sheng $\operatorname{Lin}^{1,2}$ \\ ${ }^{1}$ Inserm-U628, Integrated Physiology of Brain Arousal Systems, IFR19, 69373 Lyon, France, ${ }^{2}$ Department of Experimental Medicine, Faculty of Medicine, \\ Claude Bernard University, 69373 Lyon, France, ${ }^{3}$ Inserm-U 842, Neuro-Oncology and Neuro-Inflammation, 69372 Lyon, France, ${ }^{4}$ Department of \\ Neurophysiology, Heinrich-Heine-University, D-40001 Dusseldorf, Germany, ${ }^{5}$ Howard Hughes Medical Institute, University of Texas Southwestern \\ Medical Center, Dallas, Texas 75390-8584, and 'Department of Cellular Pharmacology, Tohoku University, School of Medicine, Sendai 980-8575, Japan
}

To determine the respective role played by orexin/hypocretin and histamine (HA) neurons in maintaining wakefulness (W), we characterized the behavioral and sleep-wake phenotypes of orexin (0x) knock-out $(-I-)$ mice and compared them with those of histidinedecarboxylase (HDC, HA-synthesizing enzyme) $-1-$ mice. While both mouse strains displayed sleep fragmentation and increased paradoxical sleep (PS), they presented a number of marked differences: (1) the PS increase in $\mathrm{HDC}^{-1-}$ mice was seen during lightness, whereas that in $O x^{-1-}$ mice occurred during darkness; (2) contrary to $\mathrm{HDC}^{-1-}, \mathrm{Ox}^{-1-}$ mice had no W deficiency around lights-off, nor an abnormal EEG and responded to a new environment with increased W; (3) only $\mathrm{Ox}^{-I-}$, but not $\mathrm{HDC}^{-I-}$ mice, displayed narcolepsy and deficient $\mathrm{W}$ when faced with motor challenge. Thus, when placed on a wheel, wild-type (WT), but not littermate $O x^{-l-}$ mice, voluntarily spent their time in turning it and as a result, remained highly awake; this was accompanied by dense $c$-fos expression in many areas of their brains, including $0 \mathrm{x}$ neurons in the dorsolateral hypothalamus. The $\mathrm{W}$ and motor deficiency of $O x^{-1-}$ mice was due to the absence of $0 \mathrm{x}$ because intraventricular dosing of orexin-A restored their W amount and motor performance whereas SB-334867 (0x1-receptor antagonist, i.p.) impaired W and locomotion of WT mice during the test. These data indicate that Ox, but not HA, promotes W through enhanced locomotion and suggest that HA and $\mathrm{Ox}$ neurons exert a distinct, but complementary and synergistic control of W: the neuropeptide being more involved in its behavioral aspects, whereas the amine is mainly responsible for its qualitative cognitive aspects and cortical EEG activation.

\section{Introduction}

From both classical and recent investigations, there is now little doubt that the posterior hypothalamus plays a key role in the maintenance of cortical activation and wakefulness (W). Indeed, since von Economo (1926) initially identified a lethargy in patients suffering from inflammatory lesions within the posterior hypothalamus, somnolence, hypersomnia, narcolepsy or coma has been repeatedly reported following lesions/inactivation of this region in several mammalian species (for review, see Moruzzi, 1972; Sakai et al., 1990; Lin, 2000; see also Sallanon et al., 1988). Recent studies have focused on the anatomical and physiological identification of neuronal substrates responsible

\footnotetext{
Received June 3, 2009; revised Sept. 4, 2009; accepted Sept. 28, 2009.

This work was supported by European Community, Fifth Framework Program Grant QLRT-2001-00826 (J.-S.L.), Inserm-U628, and Claude Bernard University. We thank Professor Y. Hou for help in the analysis of neuroanatomical data and Dr. N. Upton (Neurosciences Centre of Excellence for Drug Discovery, GlaxoSmithKline) for the generous gift of SB-334867.

Correspondence should be addressed to Dr. Jian-Sheng Lin, Inserm/UCBL-U628, Integrated Physiology of Brain Arousal Systems, Department of Experimental Medicine, Faculty of Medicine, Claude Bernard University, 8 avenue Rockefeller, 69373 Lyon Cedex 08, France. E-mail: lin@univ-lyon1.fr.

DOI:10.1523/JNEUROSCI.2604-09.2009

Copyright $\odot 2009$ Society for Neuroscience ～0270-6474/09/2914423-16\$15.00/0
}

for such an important function of the posterior hypothalamus (for review, see Lin, 2000; Saper, 2000).

The histamine (HA) neurons, located in the tuberomamillary nucleus (TM) and adjacent posterior hypothalamus, represent one of the identified populations that projects to the entire brain. These cells discharge tonically during $\mathrm{W}$ in the cat and mouse (Sakai et al., 1990; Vanni-Mercier et al., 2003; Takahashi et al., 2006), the firing pattern being the most wake-selective one so far identified in the brain. Pharmacological dosing impairing brain HA neurotransmission increases cortical slow activity. Conversely, enhancement of transmission promotes W (for review, see Monti, 1993; Lin, 2000; Passani et al., 2004; Parmentier et al., 2007). Using histidinedecarboxylase (HDC, HA-synthesizing enzyme) knock-out (KO) mice, we have shown that mice lacking HA synthesis present EEG and behavioral signs of somnolence and are unable to remain awake when high vigilance is required, such as lights-off or an environmental change (Parmentier et al., 2002). HA neurons are thought to promote cortical activation and $\mathrm{W}$ through their widespread outputs, directly or indirectly to the cerebral cortex (McCormick, 1992; Lin et al., 1996; Lin, 2000; Haas and Panula, 2003).

More recently, neurons containing the neuropeptides orexins (Ox, synonym hypocretins) have been identified in the hypotha- 
lamic dorsolateral area adjacent to HA neurons (de Lecea et al., 1998; Sakurai et al., 1998). A large body of evidence indicates that an orexin deficiency is responsible for the pathogenesis of human and animal narcolepsy (Lin et al., 1999; Chemelli et al., 1999). Like HA cells, orexin neurons send widespread projections to most brain areas and so may also play a key role in arousal (for review, see Sakurai, 2007). Finally, orexin cells increase their activity during active W (Lee et al., 2005; Mileykovskiy et al., 2005; Takahashi et al., 2008) and some anatomical/functional interactions between HA and orexin neurons, notably a direct excitation of HA neurons by Ox, have been identified (Bayer et al., 2001; Eriksson et al., 2001; Lin et al., 2002).

This indicates that both orexin and HA neurons cooperate in the hypothalamic control of the sleep-wake states and raises several questions regarding wake control, such as the respective role of the two neuronal groups located so closely together in the posterior hypothalamus, is it similar or distinct? Are the two systems coresponsible for narcolepsy? We have therefore characterized the sleep-wake phenotypes of Ox KO mice faced with behavioral and locomotive challenges and compared them with those of HDC KO mice, which were identified either in the present study or in our previous report (Parmentier et al., 2002).

Preliminary results have been presented at the 21st Annual Meeting of the Associated Professional Sleep Societies (APSS) and published in abstract form (Anaclet et al., 2007).

\section{Materials and Methods}

The EEG and sleep-wake phenotypes of histidine decarboxylase KO $\left(H D C^{-1-}\right)$ mice under baseline conditions and faced with behavioral challenges have been characterized in our laboratory (Parmentier et al., 2002). For comparison, we sought to characterize the phenotypes of prepro-orexin $\mathrm{KO}\left(\mathrm{Ox}^{-l-}\right)$ mice strictly under the same experimental conditions. In addition, to determine their sleep-wake cycle faced with a locomotive challenge, both $O x^{-1-}$ and $H D C^{-1-}$ and their wild-type (WT) counterparts were subjected to a wheel test described below.

\section{Mice and their genotyping by PCR}

All experiments followed European Ethics Committee (86/6091EEC) and French National Committee (décret 87/848) directives and every effort was made to minimize the number of animals used and any pain and discomfort. Two mouse genotypes were used in this study.

$\mathrm{Ox}{ }^{-1-}$ mice. They were descendants of the mouse strain generated by Chemelli et al. (1999) and kept on C57BL/6J genomic background by 5-9 more backcrosses during the present study. To obtain experimental animals, male $O x^{-1-}$ mice were backcrossed with female WT mice, the generated $\mathrm{Ox}{ }^{+1-}$ mice were crossed between themselves resulting in both heterozygotes and homozygotes. Only littermate homozygotes WT and KO mice ( $n=15$ pairs) were used in this study to ensure that any detected phenotype resulted from the deletion of prepro-orexin gene rather than the genetic heterogeneity between individual animals.

To determine their genotypes with respect to the orexin gene, tail biopsies were performed at age of 4 weeks for DNA detection using PCR. The KO and WT alleles were amplified using a neo primer, 5'-CCGCTATCAGGACATAGCGTTGGC and two genomic primers: 5'-GACGACGGCCTCAGACTTCTTGGG and 5'TCACCCCCTTGGGATAGCCCTTCC. The latter is common to KO and WT mice. As shown in Figure 1, a strong Ox signal, corresponding to a 400 pbs band, was detected in $O x^{+/+}$mice (animals 1-15, Fig. $1 A$ ), and a strong lacZ-neo signal, corresponding to $600 \mathrm{pbs}$ band, was detected in the $O x^{-1-}$ mice (animals 16-30, Fig. 1A).

$H D C^{-/-}$mice. Nine pairs of male inbred WT and $H D C^{-1-}$ mice were used. They were descendants of the $129 / \mathrm{Sv}$ mouse strain generated by Ohtsu et al. (2001). Their genotype with regards to the HDC gene was determined using the PCR protocol described by Parmentier et al. (2002).

\section{Surgery and polygraphic recording}

At the age of 11-13 weeks and body weight of 25-30 mg, animals were chronically implanted, under deep isoflurane anesthesia (2\% in oxygen mixed with gas anesthesia machine; TEM), with four cortical electrodes (gold-plated tinned copper wire, $\varnothing=0.4 \mathrm{~mm}$; Filotex) and three muscle electrodes (fluorocarbon-coated gold-plated stainless steel wire, $\varnothing=$ $0.03 \mathrm{~mm}$; Cooner Wire) to record the EEG and EMG and to monitor the sleep-wake cycle. All electrodes were previously soldered to a multichannel electrical connector. The cortical electrodes were inserted into the dura through two pairs of holes $(\varnothing=0.5 \mathrm{~mm})$ made in the skull, located, respectively, in the frontal ( $1 \mathrm{~mm}$ lateral and anterior to the bregma) and parietal ( $1 \mathrm{~mm}$ lateral to the midline at the midpoint between the bregma and the lambda) cortices. The EMG electrodes were inserted into the neck muscle. In some animals and for the purpose of intracerebroventricular injection, a metal guide cannula $(\varnothing=0.6 \mathrm{~mm}$, length $=10 \mathrm{~mm})$ with indwelling stylet was implanted into the lateral ventricle at coordinates of A0, L2.2 and H2.3 according to the atlas of Franklin and Paxinos (1997). Finally, the electrode assembly and cannula were anchored and fixed to the skull with Super-Bond (Sun Medical) and dental cement. This implantation allowed stable polygraphic recordings to be made for $>4$ months.

After surgery, the mice were housed individually in transparent barrels $(\varnothing 20 \mathrm{~cm}$, height $30 \mathrm{~cm}$ ) in an insulated sound-proofed recording room maintained at an ambient temperature of $22 \pm 1{ }^{\circ} \mathrm{C}$ and on a $12 \mathrm{~h}$ light/dark cycle (lights on at 7:00 A.M.), food and water being available ad libitum. For some experiments, a video camera with infrared and digital time recording capabilities was set up in the recording room to observe and score the animal's behavior during both the light and dark phases. After a $7 \mathrm{~d}$ recovery period, the animals were habituated to the recording cable for $10 \mathrm{~d}$ before starting polygraphic recording (Fig. $1 B$ ).

Cortical EEG (ipsilateral and controlateral frontoparietal leads) and EMG signals were amplified and digitalized with a resolution of 256 and $128 \mathrm{~Hz}$ respectively using a CED 1401 Plus. Using spike2 script and with assistance of spectral analysis using fast Fourier transform, polygraphic records were visually scored by 30 s epochs for wakefulness (W), slowwave sleep (SWS), and paradoxical (or rapid eye movement, REM) sleep (PS) according to previously described criteria validated for mice (Valatx, 1971; Valatx and Bugat, 1974; Parmentier et al., 2002). Narcoleptic episodes, also called direct REM sleep onset (DREMs) episodes or sleep onset REM periods by some authors (Chemelli et al., 1999; Mignot, 2005), were defined as the occurrence of PS directly from W, namely a PS episode that follows directly a wake episode lasting $>60$ s without being preceded by any cortical slow activity of more that $5 \mathrm{~s}$ during the $60 \mathrm{~s}$.

Analysis of EEG power spectral density from ipsilateral frontoparietal leads was performed for 9 pairs of $O x^{+/+}$and $O x^{-/-}$littermates during 7-10:00 P.M., period in which nocturnal rodents including mice are most active and display the highest vigilance and most characteristic behaviors. EEG power spectra were computed for consecutive $4 \mathrm{~s}$ epochs within the frequency range of $0.5-60 \mathrm{~Hz}$ using a fast Fourier transform routine. The data were collapsed in $0.4 \mathrm{~Hz}$ bins. On the basis of visual and spectral analysis, epochs containing artifacts occurring during active waking (with large movements) or immediately before or after other vigilance states were visually identified and omitted from the spectral analysis. The power densities obtained for each state were summed over the frequency band of $0.5-60 \mathrm{~Hz}$ (total power). To standardize the data, all power spectral densities at the different frequency ranges, i.e., $\delta(0.5-$ $3.5 \mathrm{~Hz}), \theta(3.5-11 \mathrm{~Hz}), \alpha$ (or spindle $11-20 \mathrm{~Hz}), \beta(20-30 \mathrm{~Hz}), \gamma(30-60$ $\mathrm{Hz}$ ), and $\beta+\gamma(20-60 \mathrm{~Hz})$, were expressed as a percentage relative to the total power (e.g., power in the $\delta$ range/power in the $0.5-60 \mathrm{~Hz}$ range) of the same epochs. To evaluate contrast in the cortical EEG between SWS and W or PS, we used an EEG power ratio determined by the averaged cortical EEG total power density during SWS divided by that during either W or PS.

\section{Experimental procedures}

In each experiment, recordings were simultaneously made from an equal number (usually in batches of three) of WT and KO 
A

Orexin $+/+$

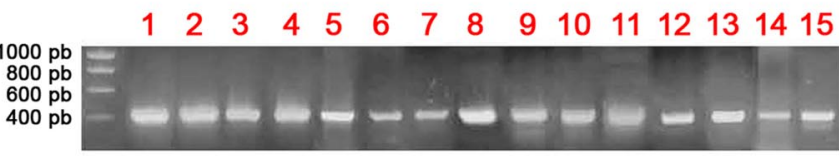

B

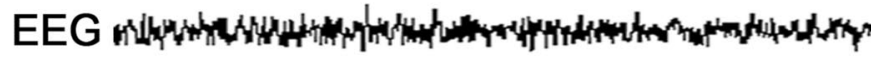

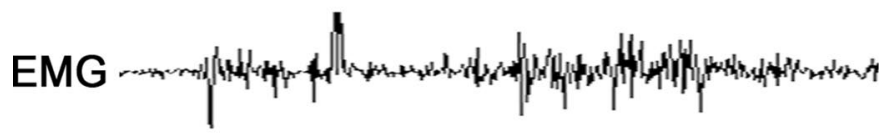

C

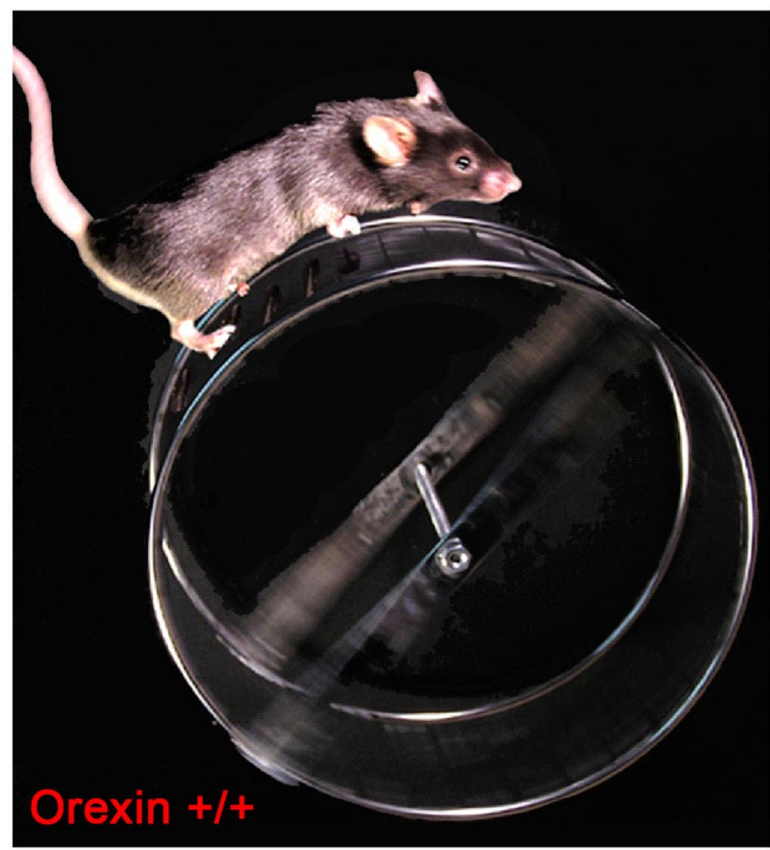

D

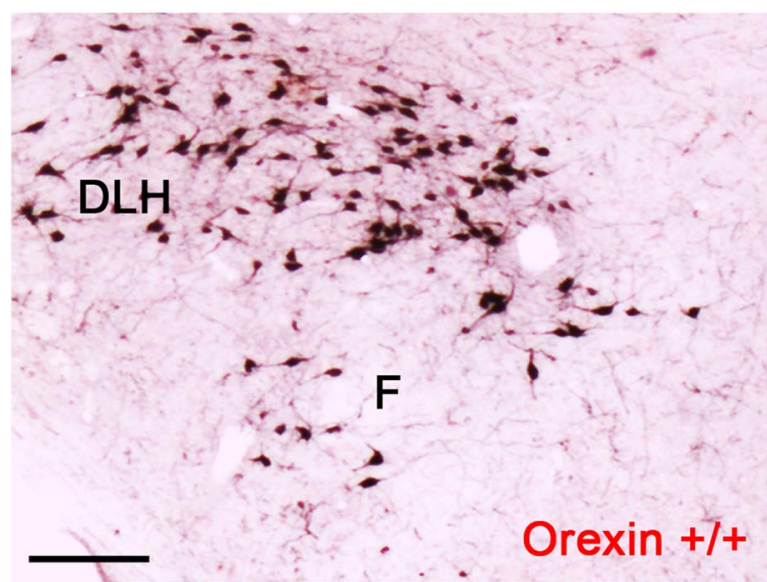

Orexin -/-

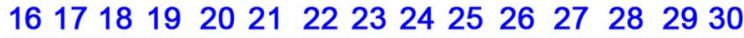
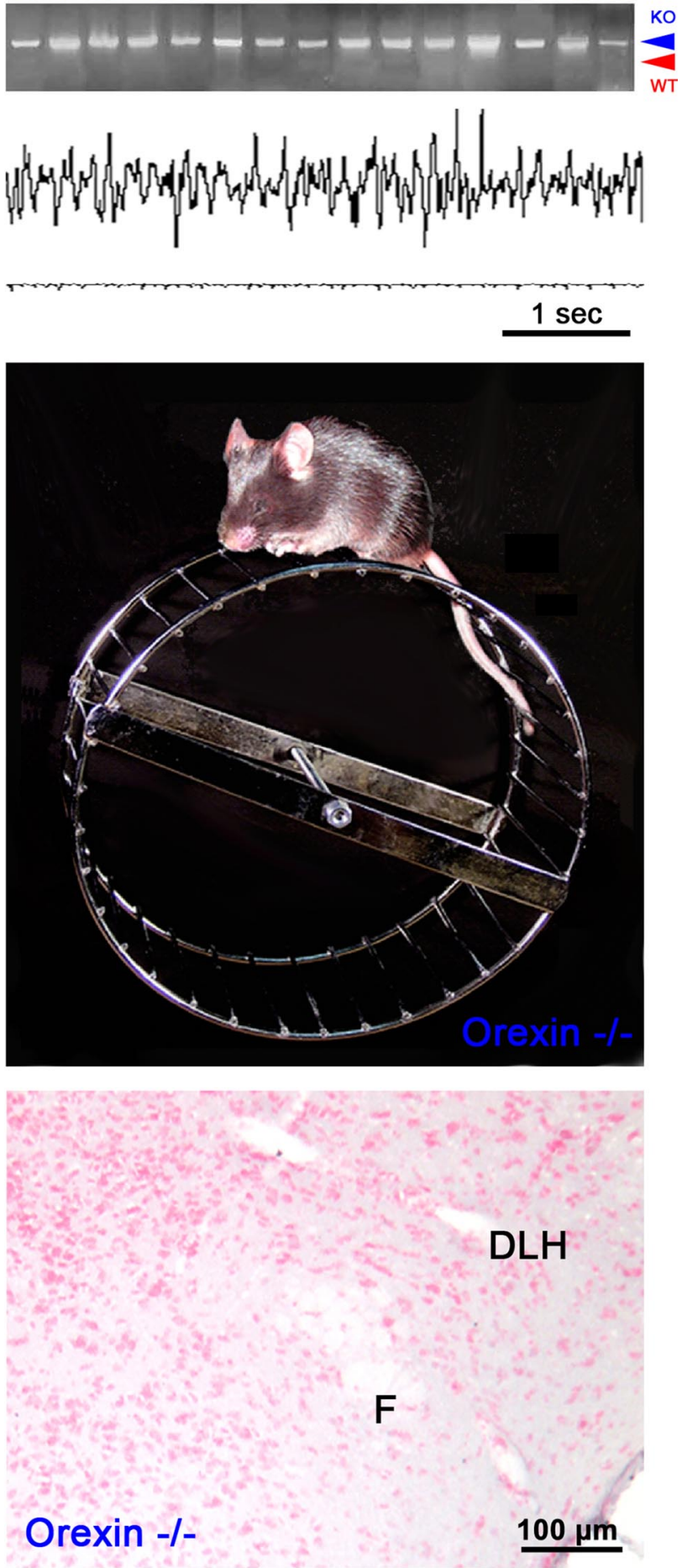

Figure 1. Illustration of the experimental procedures. A, PCR genotyping of mouse tail DNA showing the presence of prepro-orexin gene (400 pbs) in the WT mice (animals 1-15) and its absence (replaced by a 600 pbs allele) in their KO littermates (animals 16-30). B, Simultaneous recording of cortical EEG and EMG in WT and orexin KO littermates during baseline conditions or after behavioral (such as the wheel test in $\boldsymbol{C}$ ) or pharmacological tests. C, Illustration of our wheel test and the placement of mice on the wheels during the test with simultaneous EEG and EMG recordings (B). This was followed by immunohistochemical tests, such as that of orexin (D), and/or that of c-fos (see Fig. 8). DLH, Dorsolateral hypothalamic area; F, fornix.

mice (Fig. $1 B$ ). The mice were submitted to the following experimental procedures.

Spontaneous cortical EEG and sleep-wake cycle. During the period of days 15-25 after surgery, drug-naive mice were subjected to two separate $24 \mathrm{~h}$ recording sessions, beginning at 7:00 P.M. During each recording session, animals were left undisturbed.
Sleep-wake cycle after behavioral stimuli. The three following behavioral tests have been used to define the phenotypes of $H D C^{-1-}$ mice in our previous study (Parmentier et al., 2002). These tests were used here to characterize the behavioral phenotypes of WT and $O x^{-1-}$ littermates and to compare them with those of $H D C^{-1-}$ mice. Sleep-wake recordings were maintained 
during and after the tests, which were performed in a random sequence. First, a simulation of injection (at 10:00 A.M., $n=16$ from 8 pairs of animals), consisting of the handling of the animal and sham intraperitoneal injection without needle insertion; second, a change of litter (at 2:00 P.M.; $n=34$ from 9 pairs of animals), which was a routine care performed at light phase every 4-6 d to clean the cage and which usually causes a period of waking and behavioral excitation in rodents; in this test, we compared the excitability of the two groups of mice following this routine care; third, a new environment, the mice being transferred for $4 \mathrm{~h}$ from their habitual transparent barrel to an opaque rectangular box $(21 \times 30 \mathrm{~cm}$, height $20 \mathrm{~cm}$; with open field $)$, food and water being available ad libitum. In this test, the ability of the two genotypes to remain awake after this environmental change was tested. Each mouse was subjected to this test four times separated by an interval of 14-20 d, twice at 2:00 P.M. when the animals were normally sleeping for $\sim 80 \%$ of the time (defined as "sleepy period"; $n=18$ from 9 pairs of mice), and twice at 6:00 P.M. when they would normally be awake most of the time (defined as "awake period"; $n=18$ from 9 pairs of mice).

In addition, all mouse genotypes $\left(\mathrm{HDC}^{+/+}\right.$and $\mathrm{HDC}^{-/-}$; $O x^{+1+}$ and $O x^{-1-}$ ) were subjected to a motor challenge that we have designed in this study to assess the contribution of locomotion to the maintenance of $\mathrm{W}$ (Fig. 1C). The test consisted of placing mice on a wheel $(\varnothing=13 \mathrm{~cm}, 5.5 \mathrm{~cm}$ wide) which was composed of 2 circles, connected, fixed and maintained parallel by regularly spaced bars (length, $5.5 \mathrm{~cm}$; distance between bars, 9 $\mathrm{mm})$. The circles and bars were made up of stainless steel wires $(\varnothing=1.5 \mathrm{~mm})$ (Fig. 1C). The hub of the wheel was screwed to a transparent Plexiglas box ( $10 \mathrm{~cm}$ long, $7 \mathrm{~cm}$ wide, $28 \mathrm{~cm}$ high) which served to support the wheel and to prevent mice from getting off the wheel. The turning resistance of the wheel was set such that mice were able, after a few seconds of habituation, to either stay immobilized to fall asleep or to run over the regularly spaced bars to turn it and as a result to remain awake. It was therefore a largely voluntary locomotion test even though mice had to stay on the wheel during the test. The wheels were equipped with a magnetic detector, allowing quantification and computerization of the wheel turn number and time spent in turning every $30 \mathrm{~s}$ by using a homemade data acquisition system. For the test, mice were placed on the wheel, which together with the Plexiglas box was placed within each mouse's own home barrel to keep them in their familiar environment. The mice stayed on the wheel for $4 \mathrm{~h}$, food and water being available ad libitum via a supply system. In this test, we compared the ability of mice to enhance $\mathrm{W}$ and cortical activation through locomotion. Each mouse was subjected to this test six times separated by an interval of 5-10 d, three times at 2:00 P.M. and three times at 6:00 P.M. ( $n=39$ from 13 pairs of mice, for both time parameters).

To characterize the effects of the wheel test on the sleep-wake cycle and locomotion, a pretreatment was given to some littermate WT and $O x^{+/+}$mice during the lights-on period just before starting the test at 2:00 P.M., i.e., (1) intracerebroventricular injection of saline alone (control) or containing orexin-A (Ox-A) (Bachem Bioch Sarl, $3 \mu \mathrm{g} / \mu \mathrm{l}, n=16$ from 8 pairs of mice), injections being made by means of a microsyringe; the neuropeptide has a similar affinity on Ox1- and Ox2-receptors; or (2) intraperitoneal injection of vehicle (encapsin 10\% and DMSO $2 \%$ in distilled water) alone or containing SB-334867 (GSK; 30 mg/ $\mathrm{kg}, n=24$ from 12 pairs of mice), an Ox1-receptor antagonist (Duxon et al., 2001; Smart et al., 2001; Soffin et al., 2002). Sleepwake recordings subsequent to injection were made for $24 \mathrm{~h}$.
Sleep-wake stages during and after their stay in the new environment or on the wheel were compared between WT and KO mice and with the baseline recordings for the same group. As a criterion of sedation and drowsiness, the latencies to SWS and PS, defined as the time between the end of the stimuli and the onset of the first SWS or PS episode lasting $>30 \mathrm{~s}$, were also measured in the above tests.

\section{Histology and immunohistochemistry}

To determine brain neuronal activation after the wheel test, we examined $c$-fos immunoreactivity in some littermate WT and $O x^{-1-}$ mouse brains according to previously described procedures (Sastre et al., 2000) modified in the present study. Briefly, after a $2 \mathrm{~h}$ stay on the wheel, mice were removed gently from their wheel and then quickly anesthetized with pentobarbital (100 $\mathrm{mg} / \mathrm{kg}$ i. p.). They were then perfused by transcardiac route with $50 \mathrm{ml}$ of Ringer lactate solution, followed by $50 \mathrm{ml}$ of ice-cold phosphate buffer (PB) containing 4\% paraformaldehyde, $0.05 \%$ glutaraldehyde and $0.02 \%$ picric acid. After overnight postfixation and $72 \mathrm{~h}$ rinsing with $\mathrm{PB}$ containing $30 \%$ sucrose and $0.1 \%$ sodium azide, the brain was cut coronally $(25 \mu \mathrm{m})$ at $-25^{\circ} \mathrm{C}$ using a cryostat. The floating sections were incubated for $48-96 \mathrm{~h}$ at $4^{\circ} \mathrm{C}$ in $0.1 \mathrm{M} \mathrm{PB}$ saline (PBS) containing $0.3 \%$ Triton $\mathrm{X}-100$ (PBST) and $0.1 \%$ sodium azide $(\mathrm{Az})$ with a rabbit anti-c-fos antibody (AB5 Oncogene Sci., at dilutions of 1:20,000-40,000). After rinsing, the sections were incubated with biotinylated antirabbit IgG (Vector Laboratories), then with avidin-biotin-HRP complex (Elite Kit, Vector Laboratories). Both incubations (1: 2000 in PBST) were at $4^{\circ} \mathrm{C}$ overnight with stirring. After rinsing, the sections were incubated for 6-12 min at room temperature in Tris- $\mathrm{HCl}$ buffer $(0.05 \mathrm{M}, \mathrm{pH} 7.6)$ containing $0.02 \% 3-3^{\prime}-$ diaminobenzidine (DAB), $0.003 \%$ hydrogen peroxide and $0.6 \%$ nickel ammonium sulfate.

Some treated sections, notably those through the hypothalamus, were processed again for a dual-color immunostaining to determine the presence of $c$-fos labeling in orexin neurons. After many rinses, they were incubated, as described above, but using a rabbit anti-orexin-A antibody (Phoenix Europe, diluted at $1: 20,000-40,000,48-96 \mathrm{~h}$ incubation). In this second immunostaining, the immunoreactivity was revealed in Tris- $\mathrm{HCl}$ buffer $(0.05 \mathrm{M}, \mathrm{pH} 7.6)$ containing $\mathrm{DAB}(0.03 \%)$ and hydrogen peroxide $(0.003 \%)$. Thus, after these dual sequential immuroreactions, c-fos labeling displayed a blue/black color, located in cellular nuclei, whereas orexin-containing neurons stained light brown color in somata, dendrites, axons and varicosities.

Some other littermate WT and orexin KO mice were also subjected, after the sleep-wake recordings and behavioral/pharmacological tests, to orexin immunohistochemisty alone to determine the presence or absence of orexin-containing neurons in the posterior hypothalamus (Fig. 1D).

Mice subjected to intracerebroventricular injection were, at the end of sleep-wake recording and behavioral tests, injected with a blue dye $(1 \mu \mathrm{l})$ through the implanted cannula and perfused with PB containing 4\% paraformaldehyde. The location of cannula and positioning of injections were examined using standard histological methods. Only data obtained with positive lateral ventricular dye staining were taken into account in the final statistic analysis.

Finally, half of the immunoreacted sections were counterstained with neutral red to identify topographic and cellular structures. All sections were prepared for observation with a light microscope. The atlases of Franklin and Paxinos (1997) were used for the anatomical nomenclature of cerebral regions and for 
their abbreviations. To compare $c$-fos labeling between WT and $O x^{-1-}$ littermates, two types of analysis were performed for each genotype. (1) For the cortical areas and large subcortical regions, semiquantitative and proportional estimation was made up by comparison of the mean numbers of $c$-fos labeled cells obtained from three representative counting boxes $\left(0.6-1.5 \mathrm{~mm}^{2}\right)$, which were defined for each analyzed structure based on the anatomical and topographical analogy between genotypes. Five brain sections per structure were selected for evaluation. (2) Regarding the dorsolateral hypothalamic and perifornical areas and adjacent posterior hypothalamus, cell count was performed for $c$-fos or orexin stained cells or double labeling in $12 \mathrm{WT}$ and $8 \mathrm{KO}$ double stained sections using an image analyzer Histo Biocom. The cell count is presented in the text of Results as mean number \pm SEM per section.

\section{Statistical analysis}

ANOVA and post hoc Student's test (two-tailed) were used to evaluate differences between WT and KO mice in the sleep-wake and locomotion parameters under normal conditions or after treatment and differences in these parameters between control data (baseline recordings or vehicule injection) and data after treatment in the same group of animals; in the latter case, individual animal served as its own control. The same test was used to compare $c$-fos labeling in the posterior hypothalamus between genotypes.

\section{Results}

\section{General observations}

Like wild type (WT or $\mathrm{Ox}^{+/+}$) or histidine decarboxylase knockout mice (HDC ${ }^{-1-}$ or HDC KO, Ohtsu et al., 2001; Parmentier et al., 2002), prepro-orexin gene disrupted $\left(\mathrm{Ox}^{-/-}\right.$or Ox KO) mice appeared to develop normally. No abnormalities were noted in terms of general morphology, movement or other behaviors under basal conditions, with the exception of breeding. It took $>8$ weeks for a male $\mathrm{KO}$ mouse to get a frequentation of its WT female partner, instead of 4 weeks on average for a WT couple. As the number of littermates remained normal (mostly 5-7), we suggest an affected copulation in the male $\mathrm{KO}$ mice. Unlike $H D C^{-1-}$ mice which show slight obesity (Parmentier et al., 2002), the increase in body weight of $O x^{-1-}$ mice was not significantly different from WT during our study: $29.6(\mathrm{KO}) \pm 0.8$ vs $28.5(\mathrm{WT}) \pm 0.9 \mathrm{~g}$ at age of $16 \pm 1$ weeks $(n=15, p=0.37$, Student's $t$ test). No significant difference either appeared with age: $32.3(\mathrm{KO}) \pm 0.9$ vs $30.7(\mathrm{WT}) \pm 0.7 \mathrm{~g}$ at 44 weeks $(n=12$, $p=0.2)$.

\section{Comparison of spontaneous sleep-wake cycle in $\mathrm{Ox}$ and $H D C^{-/-}$mice}

Before the behavioral studies, it was necessary to obtain the EEG and sleep-wake parameters in our basal conditions to identify any possible phenotype.

With regard to sleep-wake amount, as previously reported (Parmentier et al., 2002), HDC ${ }^{-1-}$ mice displayed sleep fragmentation, an increase in PS and a deficit of W around lights-off compared with their WT counterparts (data not shown). As shown in Figure 2, Ox $x^{-1-}$ mice shared some phenotypes with $H D C^{-1-}$ mice, such as sleep or wake fragmentation, notably during darkness, e.g., the mean $\mathrm{W}$ episode duration over this period was $5.4 \pm 0.3$ instead of $12.0 \pm 1.2$ min seen with the WT littermates. This sleep fragmentation is greater than that seen with $\mathrm{HDC}^{-1-}$ mice, e.g., the numbers of $\mathrm{W}$ episodes over $24 \mathrm{~h}$ are 201 and 165 in $O x$ and HDC KO mice respectively vs 134 and 134 of their WT counterparts (Table 1).
Although an increase in PS was seen with both $\mathrm{KO}$ mice, this increase in $H D C^{-1-}$ mice was seen during lightness $(74 \pm 1.8$ vs $56 \pm 1.9 \mathrm{~min}$ in WT), leading to a $+23 \%$ increase in PS over $24 \mathrm{~h}$ (Parmentier et al., 2002), whereas in $O x^{-1-}$ mice it occurred during darkness $(26 \pm 1.6$ vs $16 \pm 1.7 \mathrm{~min}$ in WT $)$ without changing the daily amount of PS $(68 \pm 2.5$ vs $67 \pm 2.2 \mathrm{~min}$ in WT mice) because PS decreased during lightness ( $42 \pm 1.8$ vs $51 \pm 2.3$ min in WT). This bidirectional effect across light/dark phases resulted in a significant decrease in light/dark ratio of PS amount in $O x^{-l-}$ mice, i.e., $1.7 \pm 0.1$ instead of $4.0 \pm 0.8$ in WT littermates $(p=0.01$, Fig. $2 A)$.

$\mathrm{Ox}{ }^{-1-}$ mice are further distinct from $\mathrm{HDC}^{-1-}$ mice in the baseline conditions in the following ways. (1) They had no W deficiency around 7:00 P.M., the moment of lights-off. In contrast, their $\mathrm{W}$ amount increased during the light phase whereas there was a trend to decrease during darkness. As a result the dark/light ratio of $\mathrm{W}$ amount, similar to that for PS, also decreased significantly $(1.9 \pm 0.1$ vs $1.6 \pm 0.1$ in WT mice, $p=$ 0.012 ) whereas the overall $24 \mathrm{~h} \mathrm{~W}$ amount remained unchanged compared with their WT littermates (Fig. $2 B$ ). Thus, $O x^{-1-}$, but not $H D C^{-1-}$ mice, displayed an impaired circadian distribution for both W and PS. (2) As previously shown (Chemelli et al., 1999), they displayed signs of narcolepsy or DREMs, i.e., direct transitions from W to PS (Fig. 2). These narcoleptic episodes are identical to those of PS occurring normally after SWS and defined as a complete EMG atonia and an EEG dominated by well synchronized theta rhythm $(6-10 \mathrm{~Hz}$, peak power at $8 \mathrm{~Hz})$ accompanied by phasic phenomena like shaking of ears and tail. These narcoleptic episodes occurred almost exclusively during the dark period (number of episodes: $5.0 \pm 0.9$ vs $0.1 \pm 0.1$ during light period; Table 1, Fig. 2). Cataplexy, defined in dogs and humans as sudden muscle atonia during $\mathrm{W}$ (i.e., low-voltage and fast frequency waking EEG) was never noted in all used mouse genotypes during our study either under baseline conditions or during behavioral tests described below.

\section{Power spectral density of cortical EEG in $\mathrm{Ox}^{-1-}$ mice}

From the frontoparietal leads the cortical EEG of both KO animals conserved marked and specific changes across the behavioral states and signs characteristic of mice, i.e., with dominant presence of $\theta$ frequencies, notably during PS and W (Fig. 3A,D). Nevertheless, as shown in our previous study (Parmentier et al., 2002) and compared with WT mice, $H D C^{-1-}$ mice showed a decreased cortical EEG SWS/W power ratio, a decrease in cortical EEG power in theta rhythm during $\mathrm{W}$ and reduced amplitude of slow activity during SWS. In contrast to $H D C^{-1-}$ mice, $O x^{-1-}$ mice had no changes in qualitative aspects of the cortical EEG compared with those of their WT littermates (from 9 pairs of mice). First, their cortical EEG SWS/W or SWS/PS power ratio was unchanged (Fig. 3E). Second, the distribution of their mean cortical EEG power spectral density was not significantly modified during either W, SWS or PS. The morphology of their EEG spectra was virtually the same as that of their WT littermates. Finally, analysis of the mean power density in each cortical frequency band such as $\alpha, \beta, \theta, \delta$ and $\gamma$ during W, SWS and PS revealed no significant difference between the WT and KO mice (Fig. $3 A, C, D$ ).

Effects of behavioral challenges on sleep latencies and sleep-wake cycle in $\mathrm{Ox}^{-1-}$ and $H D C^{-/-}$mice

We previously demonstrated a sedative behavior and somnolence in $\mathrm{HDC}^{-1-}$ mice (Parmentier et al., 2002), i.e., they dis- 

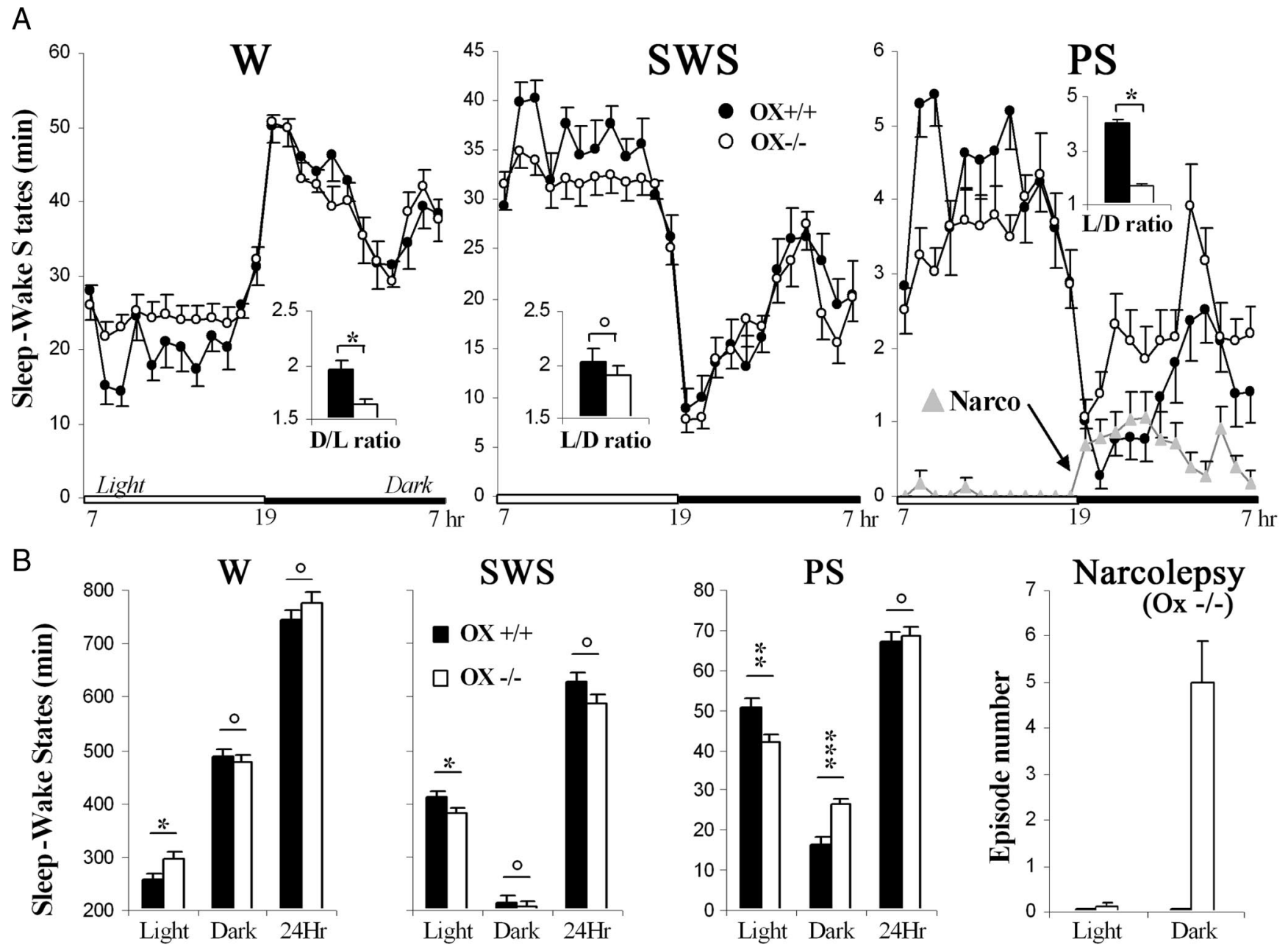

Figure 2. A, Comparison of mean hourly amount ( \pm SEM in min) of the spontaneous sleep-wake states between $0 x^{+/+}$and $0 x^{-1-}$ littermates. The inserted histograms correspond to the light/dark (L/D) ratio of the amount of each sleep-wake state. Note that $0 x^{-I-}$ mice exhibit (1) an increase in the hourly amounts of $W$ during the light period, resulting in a decrease in $D / L$ ratio of W; (2) a decrease in hourly amounts of PS during the light period, and an increase during the dark period, resulting in a marked decrease in the PSL/D ratio; (3) a decrease in the SWSL/D ratio, that is, however, not statistically significant; (4) narcoleptic episodes in $0 x^{-1-}$ mice, occurring almost exclusively during the darkness. See also Table $1 . B$, Total W, SWS, PS and narcolepsy amount during the lightness and darkness and over $24 \mathrm{~h} . n=30$, corresponding to $2 \times 24 \mathrm{~h}$ recordings for 15 animals of each genotype. ${ }^{*} p<0.05$; ${ }^{* *} p<0.01$; ${ }^{* * *} p<0.001$, using a two-tailed $t$ test after significance in a two-way ANOVA for repeated measures.

played a significant decrease in sleep latency after several behavioral tests, data confirmed here with new tests (Table 2). To determine whether the same phenotypes are present in $O x^{-1-}$ mice, they were subjected to the same tests. We found that $O x^{-1-}$ mice, compared with their WT littermates, showed a decrease in sleep latency similar to that of $H D C^{-1-}$ mice in some tests such as following a simulation of injection or a routine litter change suggesting that both mouse genotypes are less reactive than their WT counterparts. Data with two main tests, i.e., environmental change and wheel motor challenge, are detailed below.

\section{Test of new environment}

When faced with a new environment, $H D C^{-/-}$mice are characterized by a deficiency of $\mathrm{W}$, manifested as a significant decrease in sleep latencies compared with those of their counterparts (Table 2) and an inability to remain awake in the new environment. Indeed, all WT mice showed a significant increase in W during their stay in the new environment whereas the $H D C^{-1-}$ mice had no increase at all in $\mathrm{W}$ compared with their own baseline $\mathrm{W}$ (Parmentier et al., 2002). O $x^{-1-}$ mice also showed a decrease in sleep latencies when they were placed in the new environment, they differed from the $H D C^{-1-}$ mice, however, in that (1) the decrease in sleep latencies was less important than that seen with $H D C^{-1-}$ mice. For instance, the decrease in the latency to SWS in $O x^{-1-}$ mice were $-40 \%$ and $-44 \%$ respectively compared with their WT littermates at the 2:00 P.M. and 6:00 P.M. tests whereas those in $H D C^{-1-}$ mice were $-57 \%$ for both time parameters (For other comparisons, see Table 2. Note particularly the percentage changes in each experimental condition.); (2) they were able to significantly increase $\mathrm{W}$ during the $4 \mathrm{~h}$ stay in the new environment although to a lesser extent than their WT littermates (Fig. 4); (3) When mice were placed back into their home cages, $O x^{-1-}$, but not $H D C^{-1-}$ mice, showed again a significant decrease in sleep latencies (Table 2). Similar results were obtained when the test was performed at 2:00 P.M. when mice are most sleepy and at 6:00 P.M. when mice started their active and awakening period. Data obtained with the 2:00 P.M. tests are illustrated in Figure 4. The different phenotypes demonstrated here between the two genotypes indicate that the wake impairment seen with $H D C^{-1-}$ mice is mainly associated with novelty and exploration in the new environment whereas that of $O x^{-1-}$ mice 
Table 1. Episode duration (in minutes) and number of episodes of each sleep-wake state in wild-type $\left(0 x^{+/+}\right)$and orexin knock-out $\left(0 x^{-/-}\right)$littermates

\begin{tabular}{|c|c|c|c|c|c|c|c|}
\hline & \multicolumn{2}{|l|}{ W } & \multicolumn{2}{|l|}{ SWS } & \multicolumn{2}{|l|}{ PS } & \multirow{2}{*}{$\begin{array}{l}\text { Narcolepsy } \\
0 x^{-1-}\end{array}$} \\
\hline & $0 x^{+/+}$ & $0 x^{-1-}$ & $\overline{0 x^{+/+}}$ & $0 x^{-1-}$ & $\overline{0 x^{+/+}}$ & $0 x^{-1-}$ & \\
\hline \multicolumn{8}{|l|}{$24 \mathrm{~h}$} \\
\hline Number of episodes & $134.2 \pm 9.2$ & $200.6 \pm 10.4^{* * * *}$ & $143.5 \pm 8.4$ & $206.1 \pm 9.7^{* * * *}$ & $51.8 \pm 2.1$ & $54.9 \pm 2.5$ & $5.1 \pm 0.9$ \\
\hline \multicolumn{8}{|l|}{ Light period } \\
\hline Episode duration & $3.1 \pm 0.3$ & $2.9 \pm 0.1$ & $4.5 \pm 0.2$ & $3.4 \pm 0.2^{* * *}$ & $1.3 \pm 0.0$ & $1.2 \pm 0.0^{*}$ & $2.5 \pm 0.5$ \\
\hline Number of episodes & $86.5 \pm 4.7$ & $106.1 \pm 5.2^{* *}$ & $93.1 \pm 4.2$ & $114.4 \pm 4.3^{* *}$ & $38.4 \pm 2.0$ & $35.1 \pm 1.8$ & $0.1 \pm 0.1$ \\
\hline Number of episodes & $47.7 \pm 5.3$ & $94.6 \pm 5.8^{* * * *}$ & $50.4 \pm 5.1$ & $91.7 \pm 6.0^{* * * *}$ & $13.4 \pm 1.2$ & $19.8 \pm 1.4^{* *}$ & $5.0 \pm 0.9$ \\
\hline
\end{tabular}

Wakefulness

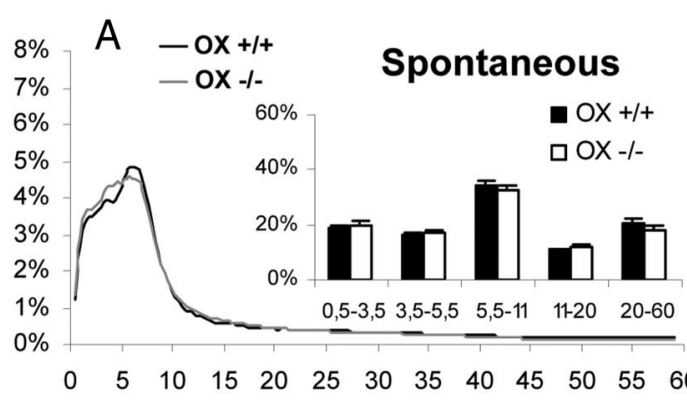

B

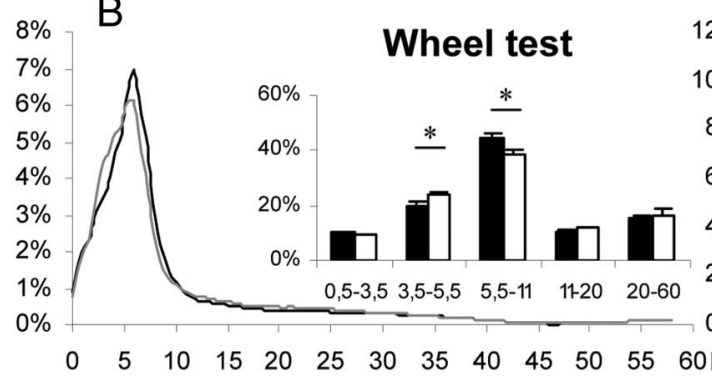

Spontaneous Sleep

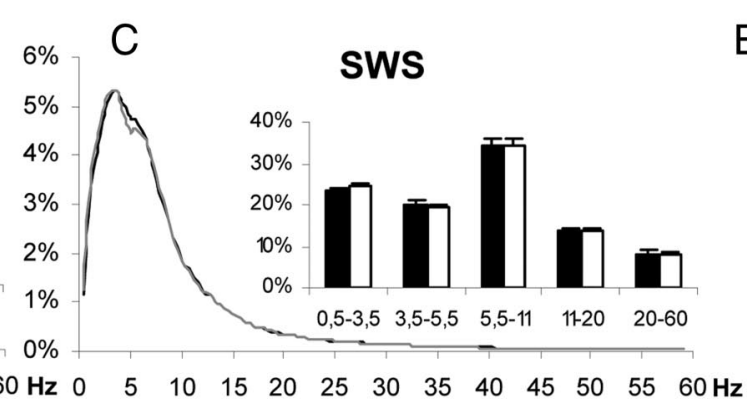

D

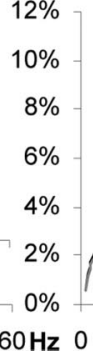

$E$

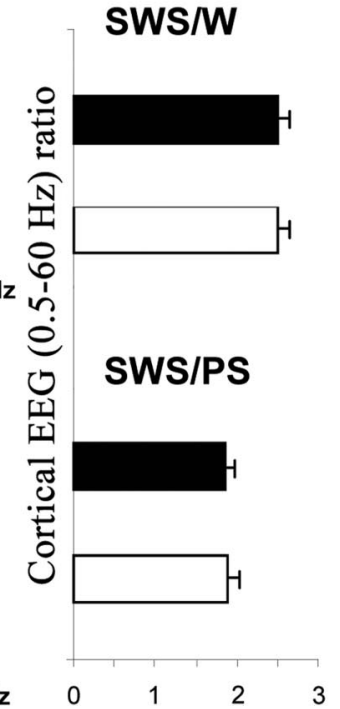

Figure 3. Mean spectral distribution of cortical EEG power density during the spontaneous sleep-wake states $(\boldsymbol{A}, \boldsymbol{C}, \boldsymbol{D})$ or the waking state during a wheel test $(\boldsymbol{B})$ in $0 x^{+/+}$and $0 x^{-/-}$mice. The data were obtained from 9 pairs of littermates by pooling consecutive $4 \mathrm{~s}$ epochs during the period of 7:00 -10:00 P.M. using the fast Fourier transform routine within the frequency range of $0.5-60 \mathrm{~Hz}$. A-D, Mean percentage power density calculated as the mean power (in square microvolts) in each $0.4 \mathrm{~Hz}$ frequency bin divided by the total power $(0.5-60 \mathrm{~Hz})$ in the same epoch. $\boldsymbol{E}$, Cortical EEG SWS/W (top) and SWS/PS (bottom) power ratio $(0.5-60 \mathrm{~Hz})$. The inset histograms in $A-D$ correspond to the EEG power spectra in $\delta(0.5-3.5 \mathrm{~Hz})$, slow $\theta(\mathrm{s} \theta, 3.5-5.5 \mathrm{~Hz})$, fast $\theta$ (f $\theta$, $5.5-11 \mathrm{~Hz}$ ), $\alpha$ (or spindle, $11-20 \mathrm{~Hz}$ ), and $\beta+\gamma(20-60 \mathrm{~Hz})$. Note, between the two genotypes, (1) the virtually similar morphology of EEG spectra during spontaneous W, SWS, and PS (A, $\boldsymbol{C}, \boldsymbol{D})$; (2) the lack of significant difference in $\alpha, \beta, \theta, \delta$, and $\gamma$ bands during W, SWS, and PS $(\boldsymbol{A}, \boldsymbol{C}, \boldsymbol{D}) ;(3)$ an unchanged cortical EEG SWS/W or SWS/PS power ratio in $0 x^{-I-}$ mice compared with their WT littermates in baseline conditions (E); and (4) an increase in slow $\theta$ band and a decrease in fast $\theta$ band in the K0 mice compared with their WT littermates during the wheel test $(\boldsymbol{B})$.

is essentially due to less behavioral reactivity faced with handling and behavioral challenges.

\section{Locomotion (wheel) test}

To assess whether HA and Ox neurons drive W through an enhancement of locomotion, all mouse genotypes were subjected to a motor challenge, which consisted of placing mice on a wheel during $4 \mathrm{~h}$. Mice were allowed to run to turn the wheel or find a position to fall asleep. The EEG, sleep-wake states and wheel turns were recorded simultaneously (Fig. $1 B, C$ ).

When both WT and $H D C^{-1-}$ mice were placed on the wheel at 2:00 P.M., the moment when mice spent maximal time in sleep, they both responded to the test with a significant increase in $\mathrm{W}$ at the expense of SWS and PS (Fig. 5C). When the sleep-wake changes seen with $H D C^{-1-}$ mice were compared with those seen in the WT mice, no statistically significant difference was noted between the genotypes in term of latencies to SWS or PS and amounts of sleep-wake states (Table 2; Fig. $5 c$ ). The number of wheel turns driven by the two mouse genotypes during the $4 \mathrm{~h}$ test, as well as their time spent in turning were also similar (316 \pm 78 turns vs $240 \pm 86, p=0.51$, Fig. $5 B$ ). Similar results were found when the test was performed during 6:00-10:00 P.M., the period when the animals were most awake, except a significant decrease in sleep latencies seen with the KO mice compared with those of WT mice, presumably as a result of a pronounced somnolence of the $\mathrm{HDC}^{-1-}$ mice identified just before and after lights-off (Parmentier et al., 2002).

In contrast, when WT and $O x^{-1-}$ littermates were placed on the wheel at 2:00 P.M., they showed clearly different phenotypes 
Table 2. Mean latencies \pm SEM (in minutes) to SWS and PS in $\mathrm{Ox}^{+/+}, \mathrm{Ox}^{-/-}, \mathrm{HDC}^{+/+}$, and $\mathrm{HDC}^{/-}$mice after behavioral or motor challenges

\begin{tabular}{|c|c|c|c|c|c|c|c|c|c|c|c|c|c|c|}
\hline & \multicolumn{2}{|c|}{ Latencies to SWS } & \multirow[b]{2}{*}{$\%$ change } & \multicolumn{2}{|c|}{ Latencies to PS } & \multirow[b]{2}{*}{$\%$ change } & \multirow[b]{2}{*}{$N$} & \multicolumn{2}{|c|}{ Latencies to SWS } & \multirow[b]{2}{*}{$\%$ change } & \multicolumn{2}{|c|}{ Latencies to PS } & \multirow[b]{2}{*}{$\%$ change } & \multirow[b]{2}{*}{$N$} \\
\hline & $0 x^{+1+}$ & $0 x^{-1-}$ & & $0 x^{+1+}$ & $0 x^{-1-}$ & & & $H D C^{+/+}$ & $H D C^{-1-}$ & & $H D C^{+1+}$ & $H D C^{-1-}$ & & \\
\hline \multicolumn{15}{|l|}{ Behavioral challenges } \\
\hline Simulation of injection & $18 \% \pm 2$ & $11 \pm 1$ & $-38^{a}$ & $44 \pm 3$ & $30 \pm 3$ & $-32^{b}$ & 16 & $16 \pm 1$ & $10 \pm 1$ & $-37^{b}$ & $49 \pm 8$ & $24 \pm 2$ & $-51^{a}$ & 26 \\
\hline Litter change & $51 \pm 3$ & $38 \pm 2$ & $-26^{c}$ & $72 \pm 4$ & $62 \pm 4$ & $-14^{a}$ & 34 & $25 \pm 1$ & $15 \pm 1$ & $-41^{d}$ & $50 \pm 2$ & $38 \pm 2$ & $-25^{b}$ & 36 \\
\hline $\begin{array}{l}\text { Environmental change at 2:00 } \\
\text { P.M. }\end{array}$ & $74 \pm 5$ & $45 \pm 5$ & $-40^{c}$ & $82 \pm 6$ & $67 \pm 7$ & -18 & 18 & $43 \pm 8$ & $18 \pm 1$ & $-57^{c}$ & $91 \pm 9$ & $51 \pm 4$ & $-44^{c}$ & 18 \\
\hline Return to home cage & $34 \pm 7$ & $14 \pm 3$ & $-58^{a}$ & $90 \pm 18$ & $40 \pm 6$ & $-55^{b}$ & & $16 \pm 3$ & $12 \pm 1$ & -23 & $29 \pm 9$ & $21 \pm 2$ & -26 & \\
\hline $\begin{array}{l}\text { Environmental change at 6:00 } \\
\text { P.M. }\end{array}$ & $122 \pm 22$ & $68 \pm 13$ & $-44^{b}$ & $191 \pm 15$ & $75 \pm 9$ & $-61^{d}$ & 18 & $36 \pm 6$ & $15 \pm 1$ & $-57^{b}$ & $110 \pm 14$ & $49 \pm 4$ & $-53^{c}$ & 22 \\
\hline Return to home cage & $39 \pm 3$ & $23 \pm 4$ & $-41^{b}$ & $80 \pm 8$ & $43 \pm 5$ & $-46^{b}$ & & $19 \pm 1$ & $18 \pm 2$ & -8 & $40 \pm 2$ & $32 \pm 2$ & -20 & \\
\hline \multicolumn{15}{|l|}{ Motor challenges } \\
\hline Wheel test at 2:00 P.M. & $72 \pm 9$ & $31 \pm 3$ & $-57^{c}$ & $157 \pm 13$ & $74 \pm 7^{d}$ & $-53^{d}$ & 39 & $41 \pm 10$ & $26 \pm 3$ & -35 & $146 \pm 15$ & $112 \pm 15$ & -23 & 18 \\
\hline Return to home cage & $38 \pm 1$ & $28 \pm 2$ & $-25^{b}$ & $64 \pm 4$ & $41 \pm 3$ & $-35^{c}$ & & $25 \pm 1$ & $17 \pm 1$ & $-29^{b}$ & $48 \pm 7$ & $36 \pm 5$ & -26 & \\
\hline Wheel test at 6:00 P.M. & $111 \pm 18$ & $35 \pm 6$ & $-68^{c}$ & $220 \pm 11$ & $99 \pm 15$ & $-55^{d}$ & 39 & $41 \pm 5$ & $27 \pm 3$ & $-34^{a}$ & $177 \pm 15$ & $112 \pm 3$ & $-37^{b}$ & 18 \\
\hline Return to home cage & $61 \pm 4$ & $35 \pm 2$ & $-43^{d}$ & $111 \pm 9$ & $69 \pm 8$ & $-37^{b}$ & & $32 \pm 3$ & $30 \pm 3$ & -7 & $77 \pm 9$ & $68 \pm 18$ & -11 & \\
\hline
\end{tabular}

A percentage change is obtained from the following formula: (latency in WT mice - latency in K0 mice)/latency in WT mice. Note (1) a significant decrease in the latencies to SWS and PS in $0 x^{-1-}$ mice after all behavioral and motor challenges, including those after their return to home cage; (2) a significant decrease in the latency to SWS in $\mathrm{HDC}^{-1-}$ mice (greater than that seen with $\mathrm{Ox}^{-1-}$ mice), occurring after an environmental change and not after their return to home cage; (3) a decrease in the latencies to SWS and PS in $\mathrm{HDC}^{-1-}$ mice (smaller than that seen with $\mathrm{Ox}^{-1-}$ mice), occurring only after a wheel test at 6:00 P.M. and not at 2:00 P.M.; and (4) a decrease in the latency to SWS in $\mathrm{HDC}^{-1-}$ mice at their return to home cage after a wheel test at 2:00 P.M. The late changes in $\mathrm{HDC}^{-1-}$ mice during the wheel test could be associated with the somnolence seen in this mouse genotype around 6:00 P.M., before lights-off. $N$, the number of tests performed in 13 pairs of $0 x^{+/+}$and $\mathrm{Ox}^{-/-}$mice and 6 to 11 pairs of $\mathrm{HDC}^{+/+}$and $\mathrm{HDC}^{-1-}$ mice.

${ }^{a} p<0.05,{ }^{b} p<0.01,{ }^{c} p<0.001,{ }^{d} p<0.0001$, compared with values from the wild-type mice, two-tailed $t$ test after significance in a two-way ANOVA for repeated measures.

in terms of motor performance and behavioral states. First, the latencies to SWS and PS were significantly shortened in the KO mice compared with those of WT ones, both when they were placed on and off the wheel (Table 2). Second, the WT mice voluntarily spent much of their time in turning the wheel and, as a result, remained highly awake (Figs. $1 C, 6 A, 7 A$ ), as demonstrated by an increase in W (184 min during $4 \mathrm{~h}$ vs 90 min during the same circadian period of baseline conditions, i.e., a net increase by $120 \%$ ) and a concomitant and dramatic decrease in SWS and PS (Figs. 6, 7). Conversely, the $O x^{-1-}$ mice did not appear to be interested in the wheel, because they spent much less time in turning it $(221 \pm 28$ turns instead of $537 \pm 84$ seen with the WT littermates, i.e., less than a half of the WT value, $p<0.01$, Figs. $6 A, 7 A$ ). Video observation showed that these $\mathrm{KO}$ mice usually tried to adapt a position between the wheel and the case wall to stay immobile, thus falling asleep (Fig. 1C) and as a result, their increase in $\mathrm{W}$ driven by the wheel test was markedly less than that of the littermate WT mice, i.e., $+45 \%$ instead of $+123 \%$. Finally, their SWS and PS amounts were about two or three times that of WT littermates subjected simultaneously to the same test (Figs. 6, 7a).

Interestingly, apart from the quantitative differences observed in motor performance and sleep-wake amount between the WT and $\mathrm{Ox} \mathrm{KO}$ mice, analysis of the cortical EEG power spectral density also revealed qualitative differences in $\mathrm{W}$ spent on the wheel between both sets of mice. Both WT and Ox KO littermates displayed signs of EEG activation during the waking state recorded on the wheel, compared with spontaneous W, manifested as an increase in theta rhythm and a decrease in $\delta$ power $(n=9$ pairs of mice for baseline EEG and $n=8$ pairs of mice for the wheel test; Fig. 3, compare $A$ with $B$ ). However, the WT and $\mathrm{KO}$ littermates displayed different levels of EEG activation as the $\mathrm{KO}$ mice showed an increase in slow $\theta(3.5-5.5 \mathrm{~Hz})$ and a decrease in fast $\theta(5.5-11 \mathrm{~Hz})$ compared with the WT littermates (Fig. 3B), suggesting less or deficient EEG activation elicited by the wheel test.

Similar quantitative and qualitative differences between the two genotypes were found when the wheel test was performed around lights-off during 6-10:00 P.M. Interestingly, $O x^{-1-}$ mice never showed any narcoleptic episode (DREM) during their $4 \mathrm{~h}$ stay on the wheel during this period, whereas in baseline conditions they exhibited $1.5 \pm 0.3$ narcoleptic episodes.
Wheel test coupled with drug administration

$O x-A$. To determine whether the $\mathrm{W}$ and motor deficiency seen with $O x^{-1-}$ mice on the wheel is, indeed, due to the lack of orexin, we performed, in both WT and $O x^{-1-}$ mice just before the wheel test during lights period, intracerebroventricular injections of $\mathrm{Ox}-\mathrm{A}(3 \mu \mathrm{g} / 1 \mu \mathrm{l})$ and compared the effects on motor performance and sleep-wake cycle between the two genotypes. $\mathrm{Ox}-\mathrm{A}$ has a similar affinity on $\mathrm{Ox}-1$ and $\mathrm{Ox}-2$ receptors. In WT mice, it caused an increase in W and decrease in SWS and PS but these effects were not significantly different from those seen in the wheel test alone (Figs. $6 A, B, 7 A, B$ ), suggesting that the orexin system in the WT mice was already largely activated by the wheel test and that additional supply of $\mathrm{Ox}$-A would not produce more pronounced effects. In contrast, the same peptide injection in $O x^{-1-}$ mice did result in a significant increase in locomotion and W, accompanied by a decrease in SWS and PS, effects being significantly different from those seen in the wheel test alone in the same mice (Fig. 6B). Thus, the Ox-A substitution corrected the motor and $\mathrm{W}$ deficient phenotype of the $\mathrm{KO}$ mice by bringing their W and locomotion amounts to those of WT mice seen either in the wheel test alone or combined with $\mathrm{Ox}$-A injection, because all these quantitative parameters became very similar and there is no more statistical difference between the two genotypes after the injection (Figs. 6B, 7B).

SB-334867. Similarly, to determine whether the enhanced W and motor performance seen with WT mice in the wheel test can be prevented by an antagonism of Ox neurotransmission, we performed, in both WT and $O x^{-1-}$ mice and just before the test during the lights period, an intraperitoneal injection of SB334867, a brain penetrating Ox-1 receptor antagonist (Duxon et al., 2001; Smart et al., 2001; Soffin et al., 2002). The antagonist at a dose of $30 \mathrm{mg} / \mathrm{kg}$ had no effects at all on W, locomotion and sleep stages in the KO mice, whereas, in contrast, the same injection did significantly decrease $\mathrm{W}$ and locomotion and increase SWS in WT littermates and, as a result, the amount of W, SWS or locomotion was brought close to that seen with $\mathrm{KO}$ mice during the wheel test alone. There is no statistical difference between the two genotypes in the above mentioned sleep-wake parameters after the antagonist injection (Figs. 6C, 7C). The effects of a suitable $\mathrm{Ox}-2$ receptor antagonist remain to be studied. 
A

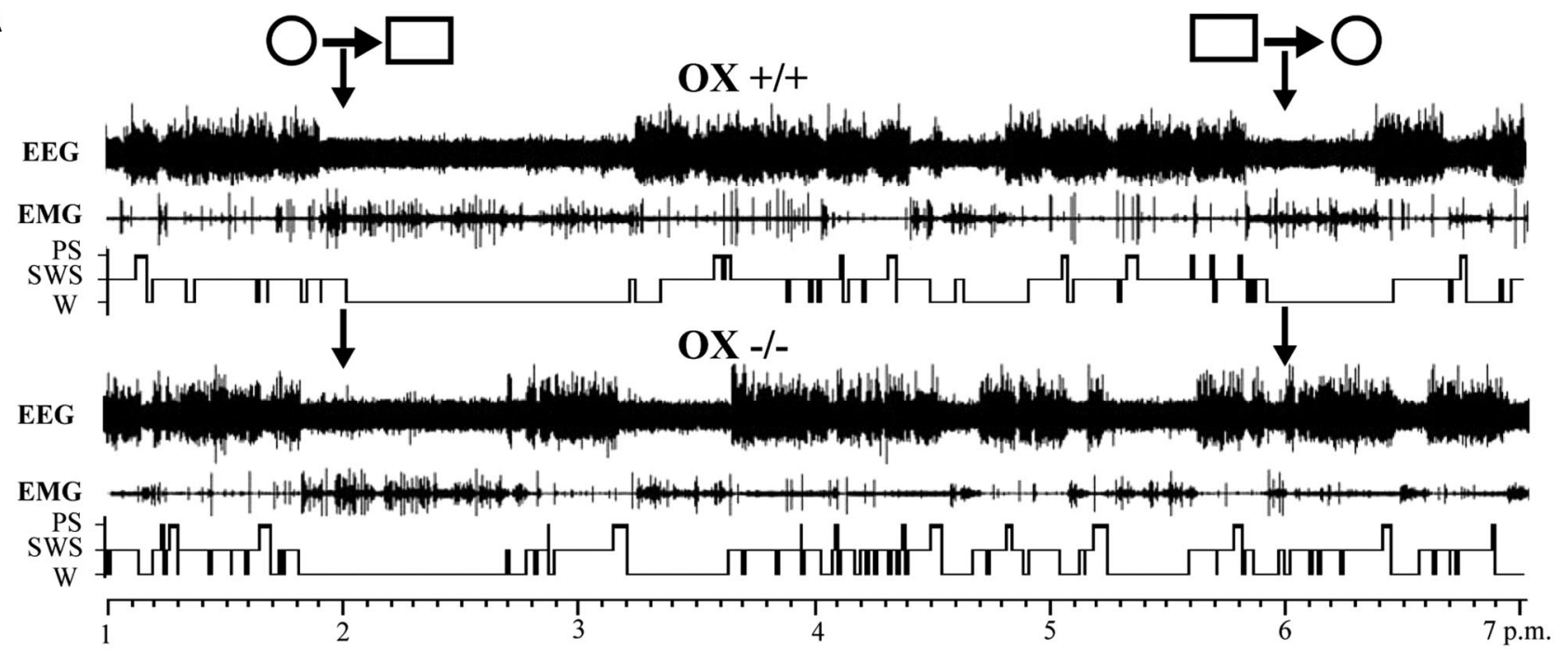

B

W

sWS

PS

Sleep-Wake change
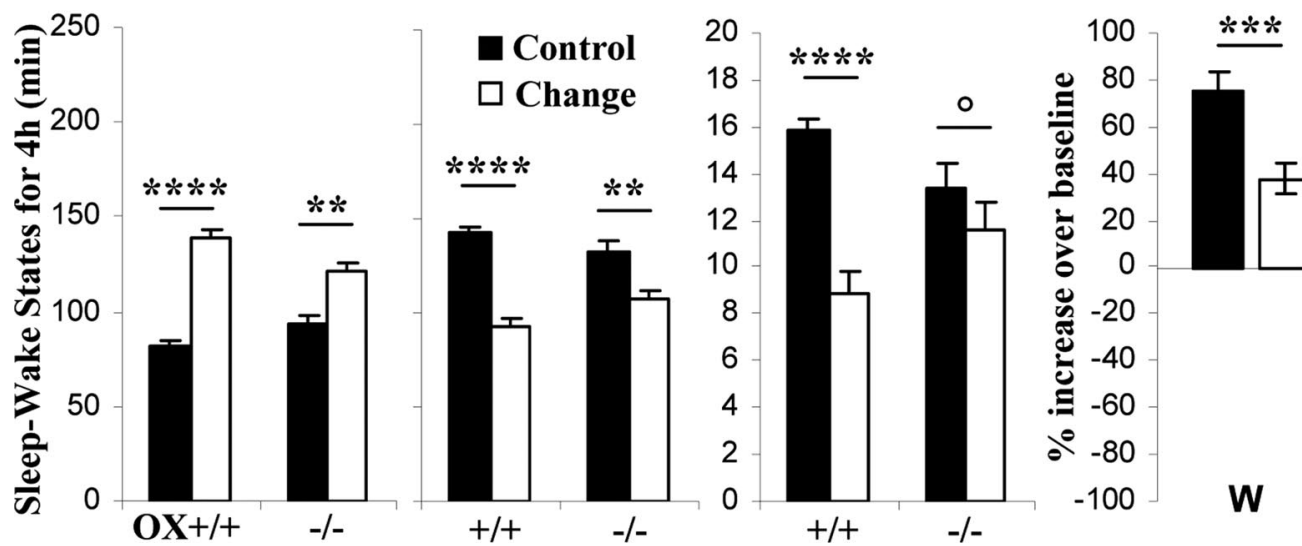

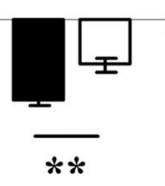

SWS

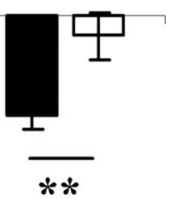

PS

Figure 4. Effects of an environmental change on the sleep-wake states in $0 x^{+/+}$and $0 x^{-1-}$ mice. $A$, Typical examples of polygraphic recording and corresponding hypnograms showing the effects of an environmental change on the cortical EEG and EMG and sleep-wake cycle. The environmental change (indicated by an arrow) consisted of moving the animals from their habitual transparent barrel cages to an opaque rectangular cage between 2:00 and 6:00 P.M. B, Quantitative variations of the sleep-wake states. Mean values \pm SEM (minutes) of each sleep-wake stage of the mice during their $4 \mathrm{~h}$ stay in the new environment are compared with those of their own baseline recordings. $C$, Sleep-wake percentage changes relative to the baseline value $(0$ axis) for the same group. Note that (1) there was a significant increase in W and decrease in SWS in $0 x^{+/+}$and $0 x^{-/-}$mice compared with their own baseline values $(A, B)$, whereas PS decreased only in $0 x^{+/+}$ mice; and (2) the sleep-wake changes in $0 x^{+/+}$mice are significantly greater than those in $0 x^{-1-}$ mice (C). $n=18$ from 9 pairs of animals. ${ }^{\circ} p>0.05 ;{ }^{*} p<0.05 ;{ }^{* *} p<0.01 ; * * * p<0.001$; ${ }^{* * * *} p<0.0001$, two-tailed $t$ test after significance in a two-way ANOVA for repeated measures.

Wheel test coupled with c-fos expression in WT and $\mathrm{Ox}^{-1-}$ littermates

Because only $O x^{-1-}$ and not $H D C^{-1-}$ mice showed wake and motor deficiency with the wheel test and to compare brain neuronal activation between $\mathrm{WT}$ and $O x^{-1-}$ littermates, we examined by immunohistochemistry the immediate early gene $c$-fos, an indicator of cellular activation after a $2 \mathrm{~h}$ wheel test in some mouse brains.

WT mice. In WT mice and in correlation with their high W amount and wheel turn number, dense $c$-fos labeling was unevenly distributed in the neocortex especially the different motor cortical areas such as the primary (Fig. $8 A$, upper left, M1) and secondary motor cortex. The somatosensory (Fig. $8 A$, upper right, S1BF) and prefrontal cortex also contained dense $c$-fos labeling. In the subcortical structures, dense expression of $c$-fos was seen in the lateral septum, paraventricular nuclei of the thalamus, midline thalamic nuclei, dorsomedial hypothalamic nucleus and dorsolateral hypothalamic area. The striatum and the large regions of the lateral hypothalamus, medial and lateral preoptic areas, diagonal bands of Broca contained moderate or scattered $c$-fos stained cells. The brainstem structures showed relatively little $c$-fos labeling except the pontine nuclei which contained dense labeling and the lateral periaqueductal gray matter, with moderate labeling.

In the middle posterior hypothalamus at the level of dorsolateral hypothalamic and perifornical areas, a moderate $c$-fos labeling ( $326 \pm 12$ per section, the same as below) showed an uneven distribution, large aggregates of labeled cells notable in the dorsolateral hypothalamic and perifornical areas $(103 \pm 5)$, dorsomedial hypothalamic nucleus $(69 \pm 7)$ and magnocellular nucleus of the lateral hypothalamus $(17 \pm 3$ ) (Fig. $8 B b-d)$. When the $c$-fos-stained brain sections were subsequently subjected to Ox immunohistochemistry, two major observations were made in the dorsolateral hypothalamic and perifornical areas. First, large $c$-fos labeled cells were Ox-immunoreactive (66 \pm 5 of $103 \pm 5,65 \%)$. Second, the great majority of Ox-containing neurons displayed dense $c$-fos labeling (Fig. $8 B a-d$ ). The double la- 


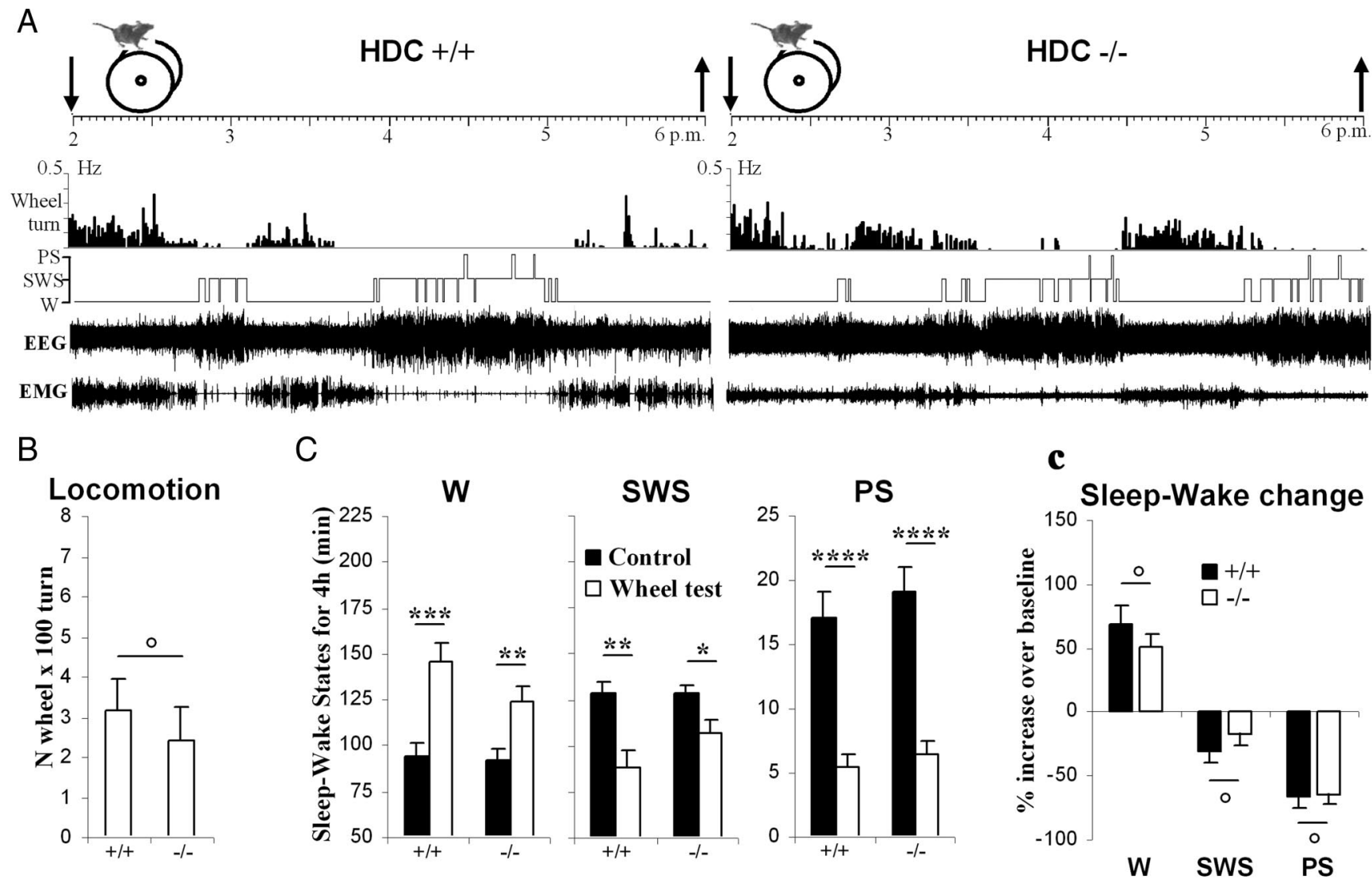

Figure 5. Effect of a wheel test on the sleep-wake states and locomotion in $\mathrm{HDC}^{+/+}$or $\mathrm{HDC}^{-1-}$ mice. $A$, Typical examples of polygraphic recording and corresponding hypnograms illustrating the effects of a wheel test on the cortical EEG and EMG and sleep-wake cycle in an $\mathrm{HDC}^{+/+}$or $\mathrm{HDC}^{-1-}$ mouse. The wheel test consisted of placing the animals on a wheel between 2:00 and 6:00 P.M. B, Effect of the wheel test on the locomotion (number of wheel turns) in $\mathrm{HDC}^{+/+}$and $\mathrm{HDC}^{-/-}$mice. C, Quantitative variations of the sleep-wake states. Mean values \pm SEM (minutes) of each sleep-wake stage of the mice during their $4 \mathrm{~h}$ stay on the wheel are compared with those of their own baseline recordings. $c$, Sleep-wake percentage changes relative to the baseline value ( 0 axis) of the same group. Note that (1) there was a significant increase in W and decrease in SWS and PS in both $H D C^{+/+}$and $H D C^{-1-}$ mice compared with their own baseline values $(A, C) ;(2)$ the wheel test induced no significantly different sleep-wake effects between the two genotypes $(\boldsymbol{c})$; and (3) the wheel test induced a similar effect on the locomotion between the two genotypes $(\boldsymbol{B}) . n=18$ from 6 pairs of animals. ${ }^{\circ} p>0.05 ;{ }^{*} p<0.05 ;{ }^{* *} p<0.01 ;{ }^{* * *} p<0.001 ;{ }^{* * *} p<0.0001$, two-tailed $t$ test after significance in a two-way ANOVA for repeated measures.

beled cell bodies represented $84 \%$ of Ox-containing cells (Fig. $8 B a, b, 66 \pm 5$ of $79 \pm 7$, with a typical example of $92 \%$ seen in the section illustrated). These results indicated that in this region, large $c$-fos labeling was orexinergic and that the great majority of Ox neurons was activated during the wheel test.

Brain structures believed to play an important role in arousal, wake maintenance or behavioral activation such as the intralaminar nuclei of the thalamus, the histaminergic tuberomamillary nucleus, the dopaminergic sustantia nigra and ventral tegmental area, the noradrenergic locus ceruleus as well as the cholinergic basal forebrain and mesopontine tegmentum contained only a few scattered labeled cells.

$O x^{-/-}$mice. In sharp contrast and in correlation with their lower $\mathrm{W}$ amount and wheel turn number, $\mathrm{O} x^{-1-}$ littermates showed after $2 \mathrm{~h}$ stay on the wheel much less $c$-fos labeling in the majority of the brain areas especially in the neocortex. For instance, the primary and secondary motor cortex and the somatosensory cortex were estimated to have only $1 / 3$ to $1 / 6$ of the labeled cells, compared with those of the WT mice (Fig. $8 \mathrm{~A}$, middle left and right, M1 and S1BF). In the subcortical areas, such as the lateral septum, paraventricular nuclei of the thalamus and other thalamic nuclei, striatal nuclei, medial and lateral preoptic areas and diagonal of bands of Broca, lateral hypothalamic areas, the number of stained cells were also clearly less than that seen in the same structures of WT mice. The number of labeled cells in these areas was estimated to be $1 / 2$ to $1 / 4$ of that of the same structures in the WT littermates.

In the middle posterior hypothalamus, the number of $c$-fos stained cells is also inferior to that seen in the WT littermates: $208 \pm 7$ vs $326 \pm 12(-36 \%, p<0.01)$ (Fig. 8 Bb1-d1) especially, the two aggregates seen in the WT dorsomedial hypothalamic nucleus and magnocellular nucleus of the lateral hypothalamus were found with a significant: decreased numbers, from $69 \pm 7$ to $37 \pm 5(-46 \%)$ and $17 \pm 3$ to $4 \pm 1(-80 \%)$, respectively $(p<$ 0.01 , Fig. $8 B$, compare $b 1-d 1$ with $b-d)$. Interestingly and remarkably, in the dorsolateral hypothalamic and perifornical areas where Ox neurons were located in the WT mice and showed dense $c$-fos labeling, a large group of $c$-fos stained cells was present. Their number $(83 \pm 4)$ was inferior, but quite close, to that of $103 \pm 5$ in WT mice $(-19 \%)$. Their location and distribution remained those of Ox neurons in the WT mice (Fig. $8 B$, compare $a 1-d 1$ with $a-d$ ). Whether these stained neurons correspond to Ox-containing neurons normally present in the WT mice and represent "Ox neurons" without Ox in the KO mice remains to be determined. In the rat, Ox neurons represent $<10 \%$ of all cells in the perifornical area (Modirrousta et al., 2005); this proportion appeared to be higher in the mice after our slight neutral red counterstaining (Fig. 1D), but this assumption needs to be quantified using denser staining and adequate histological approaches. Nevertheless, dorsolateral hypothalamic and 

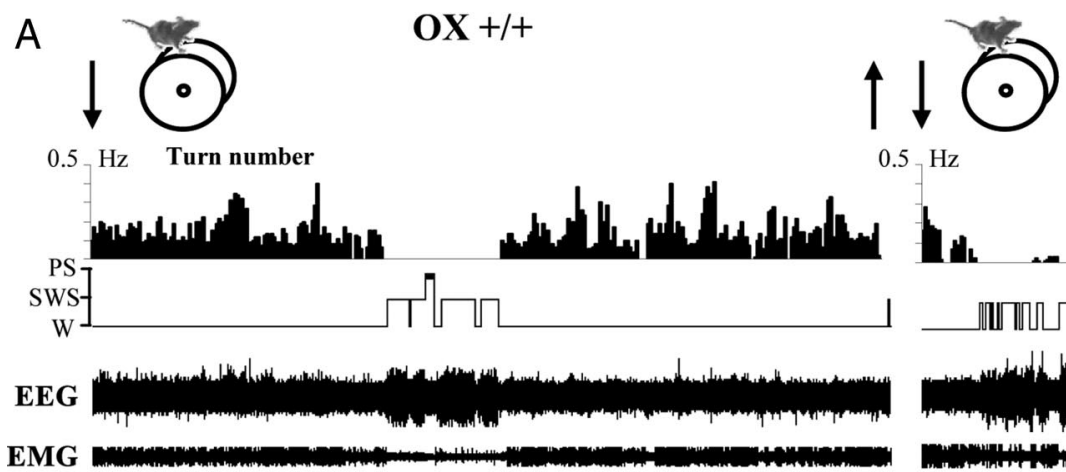

OX -/-

B
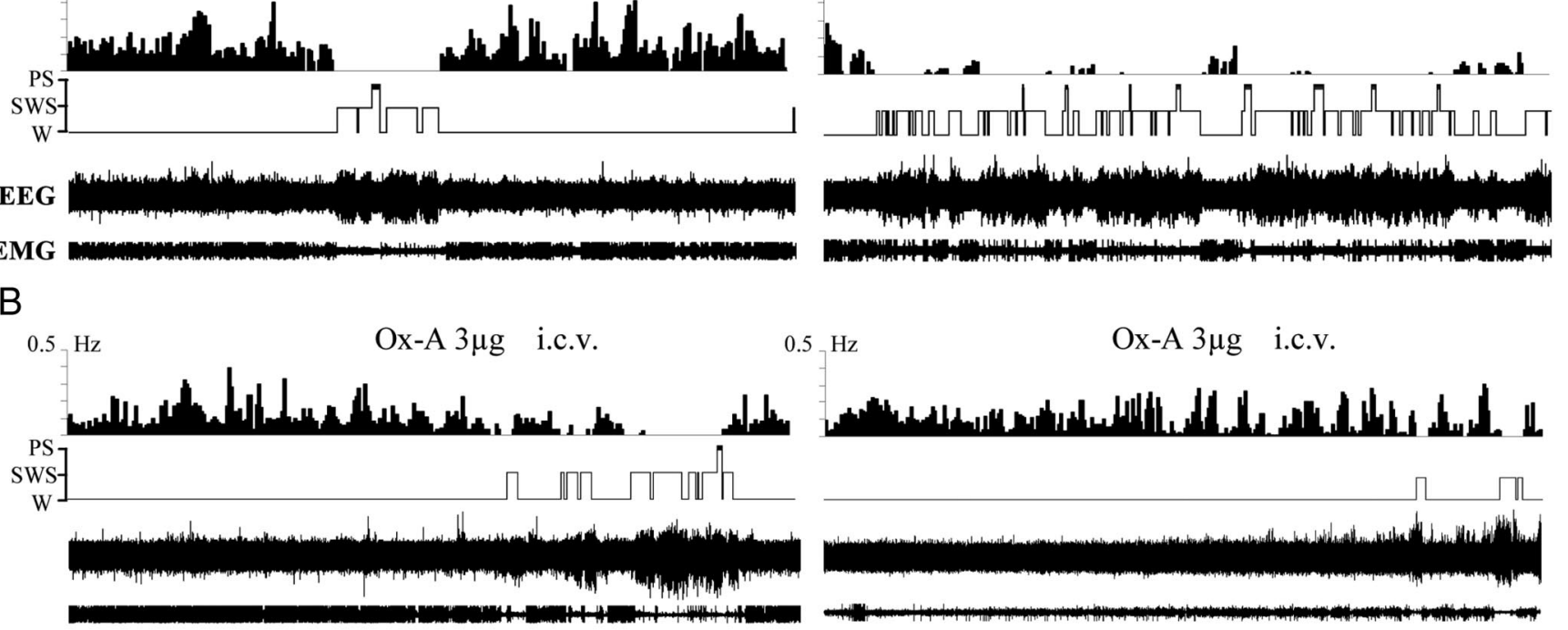

C
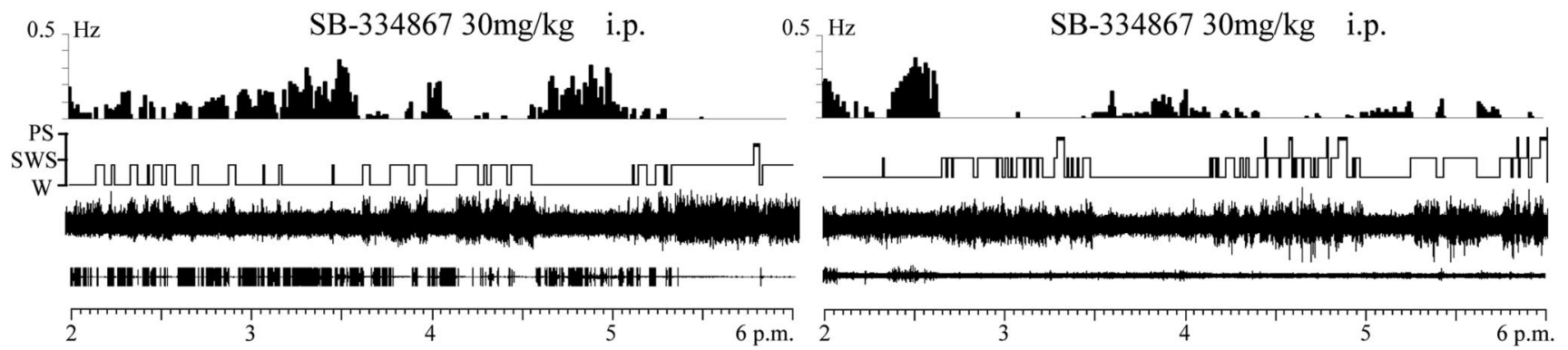

Figure 6. Typical examples of polygraphic recording (EEG and EMG) and corresponding hypnograms illustrating the effects of a wheel test, alone or combined with pharmacological dosing, on the locomotion and sleep-wake states in $0 x^{+/+}$and $0 x^{-1-}$ mice. $A$, Wheel test alone. Note a much larger amount of wheel turns and W in $0 x^{+/+}$mice than $0 x^{-1-}$ mice. $\boldsymbol{B}$, Wheel test coupled with intracerebroventricular injection of $0 \mathrm{x}-\mathrm{A}$ at a dose of $3 \mu \mathrm{g}$. Note that, after dosing, the $0 x^{+/+}$mouse maintained its high amount of locomotion and W, whereas the $0 x^{-1-}$ mouse showed a remarkable improvement of W and number of wheel turns (compare $B$ with $A$ ) and that the amount of locomotion and W in the $0 x^{-/-}$mouse became similar to that of the $0 x^{+/+}$mouse. $\boldsymbol{C}$, Wheel test coupled with intraperitoneal injection of SB-334867 (Ox-1 receptor antagonist) at a dose of $30 \mathrm{mg} / \mathrm{kg}$. Note that the antagonist impaired the wheel test-induced locomotion and W only in the $0 x^{+/+}$mouse (compare $\mathbf{C}$ with $\boldsymbol{A}$ ).

perifornical neurons in the KO mice are likely to be activated after the wheel test although the number of neurons involved seems to be less than that of the WT littermates.

Like that in $\mathrm{KO}$ mice, brain structures believed to promote cortical or behavioral arousal and $\mathrm{W}$, such as the histaminergic tuberomamillary nucleus and other regions mentioned above, showed only a few scattered labeled cells. It should be mentioned here that no KO brain structure was found with a greater number or higher intensity of $c$-fos labeling than that of the WT mice.

Genotype confirmation by PCR and immunohistochemistry Finally, the genotype with respect to the prepro-orexin (Fig. 1A) or hdc gene of all mice studied was confirmed using PCR. Immunohistochemistry using $\mathrm{Ox}$-A or HA antibodies revealed absence of Ox-containing neurons (Fig. 1D) in the Ox KO mice and that of HA neurons in $H D C^{-1-}$ mice.

\section{Discussion}

We report here a number of common and of distinct phenotypes in $O x^{-1-}$ and $H D C^{-1-}$ mice. Whereas sleep fragmentation oc- curs in both, many other phenotypes are clearly different. Unlike $\mathrm{HDC}^{-1-}, \mathrm{Ox} \mathrm{x}^{-1-}$ mice presented normal wakefulness (W) around lights-off or over $24 \mathrm{~h}$, even though their $\mathrm{W}$ and paradoxical sleep (PS) circadian distribution was disturbed. Their cortical EEG was unimpaired and they were able to respond to a new environment with increased W. Finally, in stark contrast to $H D C^{-1-}, O x^{-1-}$ mice displayed a marked defect in EEG activation, $\mathrm{W}$ and brain $c$-fos expression when faced with a motor challenge. This is the first study, to our knowledge, that compares the sleep-wake and behavioral phenotypes of the two mouse strains in identical experimental conditions, that shows important different phenotypes between them and that reveals the distinct roles of the neuropeptide and the amine in wake control.

Posterior hypothalamus and control of wakefulness A key role of the posterior hypothalamus in the maintenance of cortical activation and W is now generally accepted. It is the only brain structure so far identified, in which lesioning or inactivation using the GABA agonist, muscimol, results in hypersomnia in several species and restores sleep in various insomniac models 
in the cat (Sallanon et al., 1988, 1989; Lin et al., 1989; Lin, 2000). Moreover, it is the only area studied so far, in which several types of wake selective neurons are identified (Sakai et al., 1990, Steininger et al., 1999; Vanni-Mercier et al., 2003, Lee et al., 2005; Mileykovskiy et al., 2005; Takahashi et al., 2006, 2008, 2009).

The identification of histamine (HA) neurons exclusively in the posterior hypothalamus in the 1980s and the drowsiness and sedative side effects of classic antihistaminic drugs have led to the assumption that HA neurons could be responsible for such an important function (Lin et al., 1988, 1996; Schwartz et al., 1991; Haas and Panula, 2003). This view is well supported (see Introduction), notably, in midbrain-transectioned cats in which the cerebral cortex presents continuous high voltage slow activity without spontaneous activation similar to that seen in coma, the use of small doses of an H3-receptor inverse agonist activates HA neurons and restores a sustained cortical activation (Lin, 2000).

The posterior hypothalamus is a heterogeneous structure containing diverse neuronal groups (Saper, 2000). Ox neurons are neighbors of HA neurons and through their widespread projections, are thought to promote $\mathrm{W}$, in addition to their major role in preventing narcolepsy (Chemelli et al., 1999; Sakurai, 2007). Several findings from this and other studies indicate that, although both systems promote $\mathrm{W}$, their involvement is likely to be distinct, notably under different behavioral contexts during $\mathrm{W}$.

\section{Orexin neurons and behavioral aspects} of wakefulness

$O x^{-1-}$ mice displayed marked deficiencies of EEG activation, $\mathrm{W}$ and locomotion, accompanied by a decrease in $c$-fos expression in the major brain areas when faced with a motor challenge in our wheel test. A recent study also showed a decreased locomotion in $O x^{-1-}$ mice, without W deficiency (España et al., 2007). This study used spontaneous and chronic access to a wheel, a test different to ours. We further demonstrated that the motor and wake deficiency in $O x^{-1-}$ mice was, indeed, due to the lack of Ox because its substitution with Ox-A rescued the defect, allowing the KO mice to recover a normal level of $\mathrm{W}$ and motor performance during the challenge. Furthermore, the Ox-1 receptor antagonist $\mathrm{SB}$ 334867 had no effect in the KO mice during the same test, but did impair W and locomotion in the WT mice, mimick-
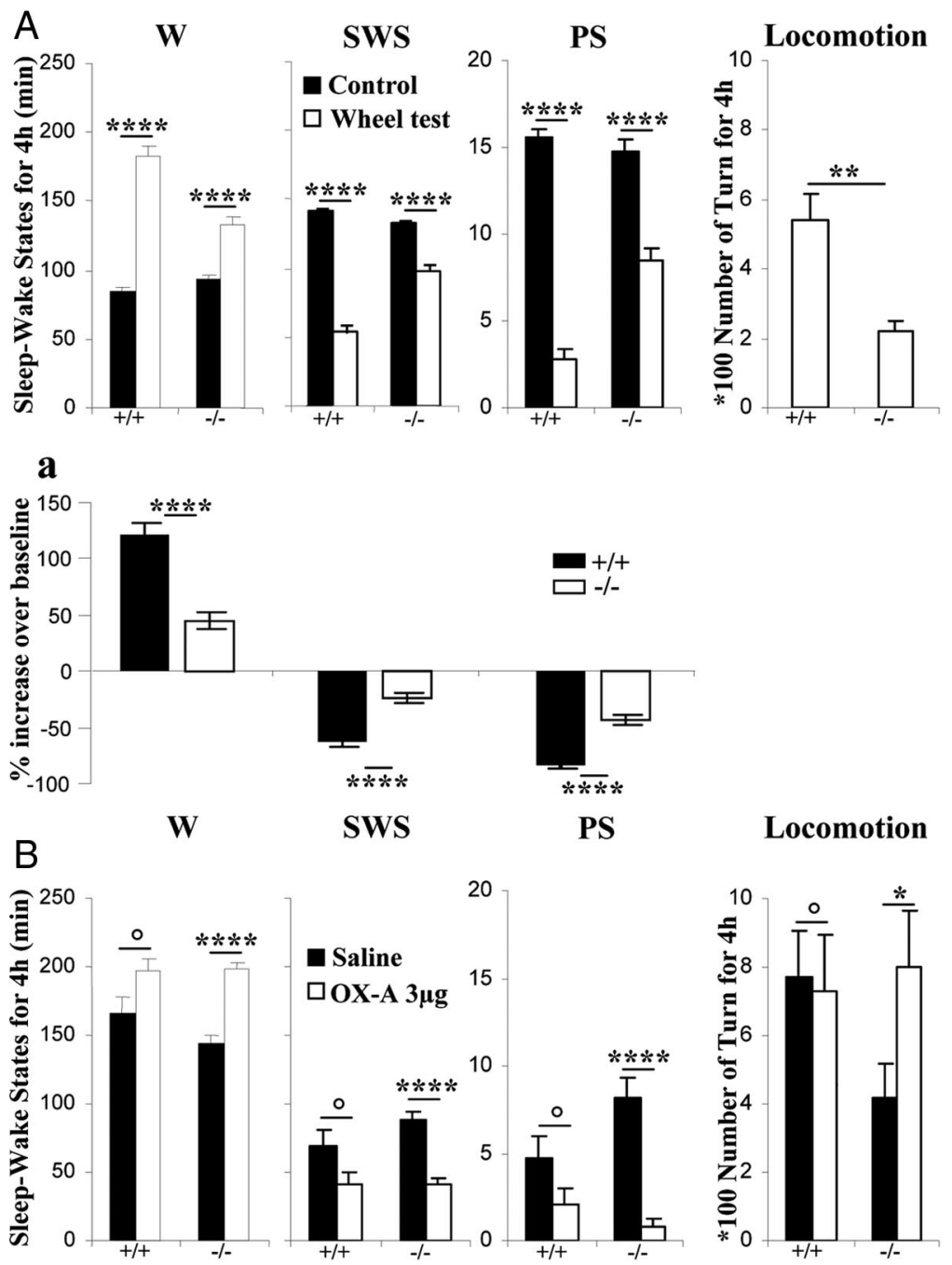

Locomotion

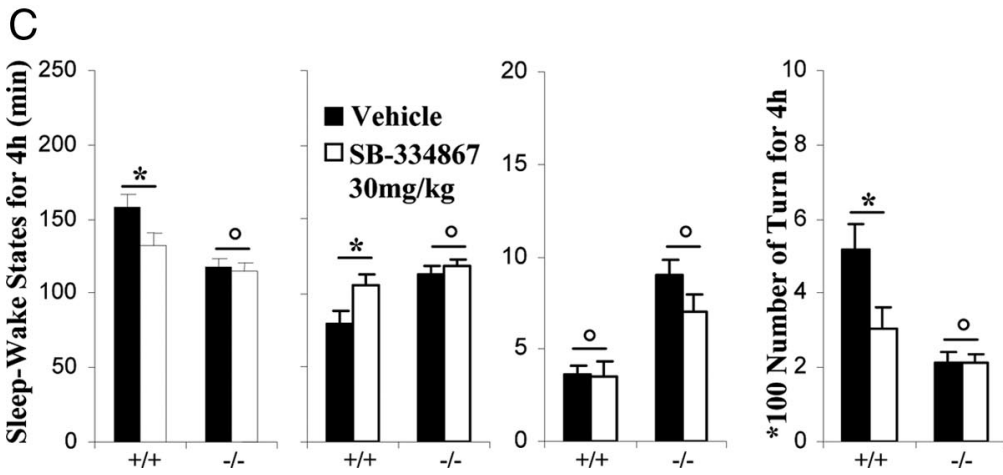

Figure 7. Comparison of the effects of a wheel test, alone or combined with pharmacological dosing, on the locomotion and sleep-wake states in $0 x^{+1+}$ and $0 x^{-1-}$ mice. $A$, Wheel test alone. Note (1) a significant increase in $W$ and a significant decrease in SWS and PS in both $0 x^{+1+}$ and $0 x^{-1-}$ mice during the wheel test lasting $4 \mathrm{~h}$ compared with their own baseline values, and (2) a significantly higher amount of wheel turns in $0 x^{+1+}$ than in $0 x^{-1-}$ mice. $\boldsymbol{a}$, Sleep-wake percentage changes relative to the baseline value ( 0 axis) for each mouse genotype. Note that the sleep-wake changes during the wheel test are highly significantly smaller in $0 x^{-1-}$ than in $0 x^{+1+}$ mice. $n=39$ tests in 13 pairs of mice. $\boldsymbol{B}$, Wheel test coupled with intracerebroventricular injection of $0 \mathrm{x}-\mathrm{A}$ at a dose of $3 \mu \mathrm{g}$. Note that the agonist significantly increased W and locomotion and decreased SWS and PS in $0 x^{-1-}$ mice during the wheel test but had no effect in $0 x^{+1+}$ mice. $n=16$ tests from 8 mice of each genotype. C, Wheel test coupled with intraperitoneal injection of SB-334867 (0x-1 receptor antagonist) at a dose of $30 \mathrm{mg} / \mathrm{kg}$. Note that the antagonist significantly decreased $\mathrm{W}$ and locomotion and increased SWS and PS in $0 x^{+1+}$ mice during the wheel test but had no effect in $0 x^{-1-}$ mice. $n=24$ injections performed in 12 mice of each genotype. ${ }^{\circ} p>0.05 ;{ }^{*} p<0.05 ;{ }^{* *} p<0.01 ;{ }^{* * *} p<0.001 ;{ }^{* * * *} p<0.0001$, two-tailed $t$ test after significance in a two-way ANOVA for repeated measures. 


\section{A}
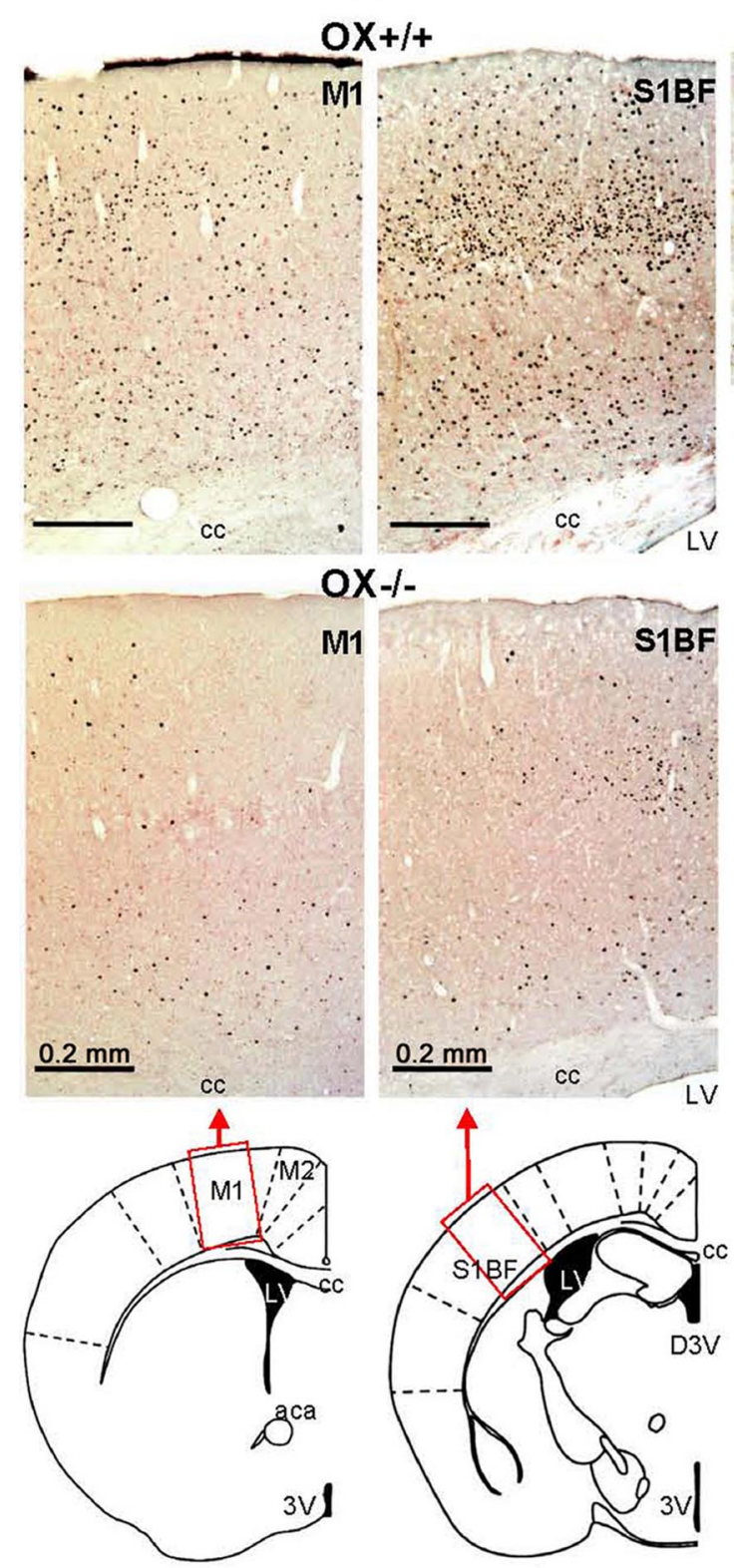

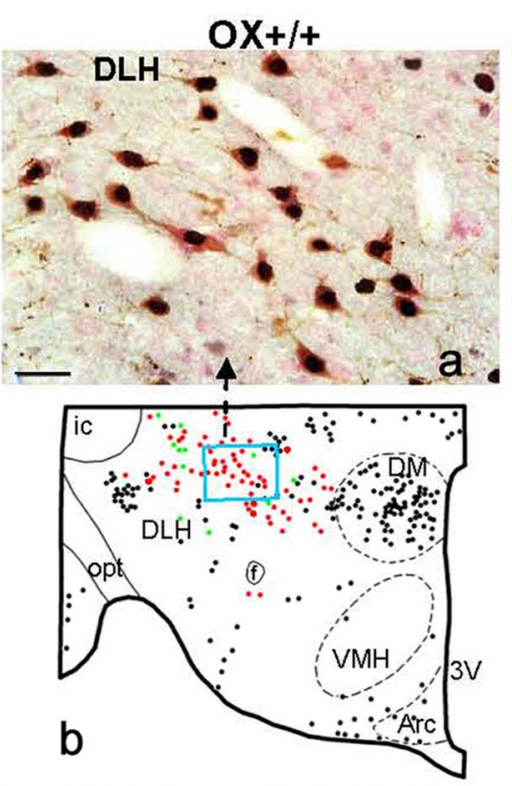

B
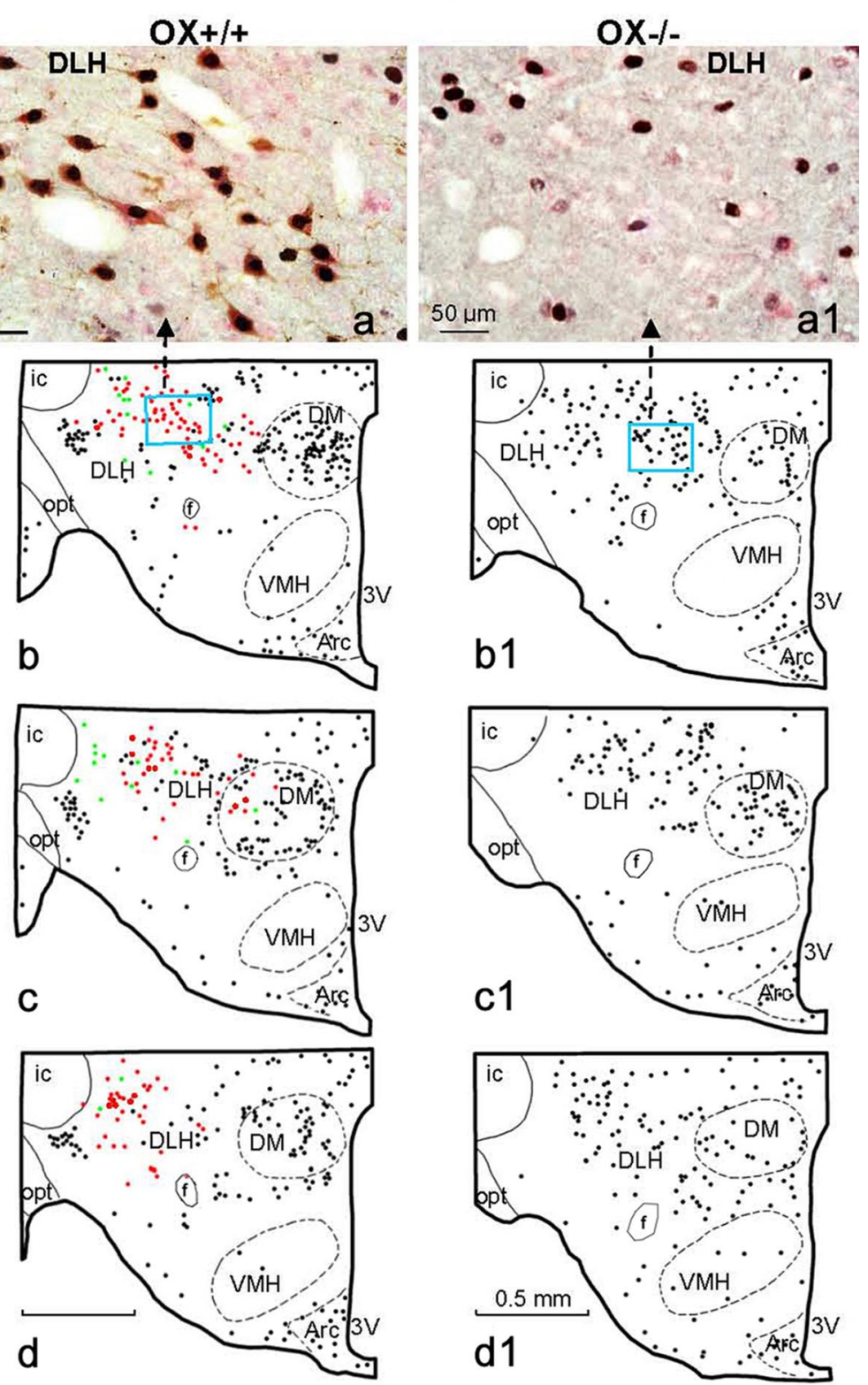

Figure 8. Effects of a wheel test on c-fos expression in the $0 x^{+/+}$and $O x^{-1-}$ mouse brains. A, Photomicrographs illustrating the distribution of Fos-immunoreactive neurons in the cerebral cortices. Examples of frontal sections across the primary motor cortex (M1) and somatosensory 1 cortex (barrel field, S1BF) are shown. The anatomical location of the two photomicrographs is indicated by the schematic frontal sections (left, lower). Note, in both structures, a remarkably higher density of c-fos labeling in the $0 \mathrm{x}^{+/+}$than in the $0 \mathrm{x}^{-/-}$mouse cortices following a $2 \mathrm{~h}$ stay on the wheel. $\boldsymbol{B}$, Camera lucida drawing of frontal sections showing the distribution of simple Fos (black dots)- or 0x (green dots)-immunoreactive cells and double Fos- and 0x-immunoreactive neurons (red dots) in the posterior hypothalamus. The upper right examples in the photomicrograph ( $\boldsymbol{a}$ and $\boldsymbol{a}$ ) are made from the dorsolateral hypothalamic area (DLH), indicated by a blue inset from the rostral sections of the posterior hypothalamus $(\boldsymbol{b}$ and $\boldsymbol{b} 1)$. Note, after a $2 \mathrm{~h}$ stay on the wheel, 1 ) that large $c$-fos labeling in the DLH is $0 \mathrm{x}$-immunoreactive and that the great majority of $0 x$-containing neurons (stained brown) shows c-fos labeling (black nuclei) in the $0 x^{+/+}$mouse $(\boldsymbol{a}-\boldsymbol{d})$, and (2) that in the $0 x^{-1-}$ mouse $(\boldsymbol{a} 1-\boldsymbol{d} 1)$, no $0 x$-immunoreactive cell is detected (see also Fig. 1D), but an important c-fos labeling is present. 3V, Third ventricle; aca, anterior commissure, anterior; Arc, arcuate hypothalamic nucleus; cc, corpus callosum; D3V, dorsal third ventricle; DM, dorsomedial hypothalamic nucleus; f, fornix; ic, internal capsule; LV, lateral ventricle; M2, secondary motor cortex; opt, optic tract; VMH, ventromedial hypothalamic nucleus. Bars, $0.1 \mathrm{~mm}$ (left) and $0.5 \mathrm{~mm}$ (right).

ing the phenotype presented by the KO littermates. Finally, the lack of neuronal release of the neuropeptide per se, rather than that of neurons synthesizing it, is likely to be the direct cause of this phenotype in the $\mathrm{KO}$ mice, as cells in the dorsolateral hypothalamus, most likely ex-Ox neurons, expressed c-fos indicating activation during our motor challenge. Whereas this hypothesis remains to be verified using other markers of $\mathrm{Ox}$ neurons, our findings are consistent with a large body of experimental data supporting a major role of $\mathrm{Ox}$ in active $\mathrm{W}$ and locomotion:
These neurons display a $\mathrm{W}$-active discharge pattern, clearly correlated to muscle tone and posture change, with a significant decrease from active $\mathrm{W}$ to quiet $\mathrm{W}$ and from quiet $\mathrm{W}$ to slowwave sleep (SWS) (Lee et al., 2005; Mileykovskiy et al., 2005; Takahashi et al., 2008). In the rat, the discharge rate of Ox neurons during active $\mathrm{W}$ is $>4.5$ times that of quiet $\mathrm{W}$ (Lee et al., 2005; Mileykovskiy et al., 2005), indicating that their main activity is to promote behavioral activation during W. CSF Ox-A level (Martins et al., 2004) or c-fos expression in Ox neurons (Torterolo et al., 2001; Valdés et al., 2005) increase after forced W or behav- 
ioral activation. Finally, central application of orexins elicits active arousal and hyperactivity in rats, an effect prevented by SB-334867 (Hagan et al., 1999; Jones et al., 2001). Together, these results suggest that Ox neurons promote locomotion and behavioral arousal and thus contribute to the maintenance of $\mathrm{W}$ by enhancing locomotion.

\section{Histamine neurons and qualitative cognitive aspects of wakefulness}

In contrast to $O x^{-1-}$ mice, no significant deficiency of $\mathrm{W}$ and motor performance could be detected in $H D C^{-1-}$ mice when subjected to the same wheel test even during the lights-off period when $H D C^{-1-}$ mice show abnormal somnolence. Further data speak against the direct involvement of HA in locomotion. First, HA neurons fire in a tonic and regular pattern across the whole wake episode, with a ratio of 1.5 between active/quiet $\mathrm{W}$ in the cat (Sakai et al., 1990; Vanni-Mercier et al., 2003), much lower than that of $>4.5$ for Ox cells in rats. Unfortunately, this ratio is so far not fully clear in mice because the sleep-wake discharge of hypothalamic neurons was recorded in head-restraint rather than freely moving conditions (Takahashi et al., 2006, 2008, 2009). Second, selective activation or inactivation of HA neurons does not result in clear and specific effects on motor performance (Schwartz et al., 1991; Haas and Panula, 2003; Haas et al., 2008), e.g., pharmacological disinhibition of HA neurons by H3receptor inverse agonists results in quiet $\mathrm{W}$ without overt behavioral activation and enhanced locomotion (Parmentier et al., 2007; Lin et al., 2008). It seems therefore unlikely that HA neurons promote $\mathrm{W}$ by enhancing locomotion.

What is then the respective role of HA neurons compared with that of Ox cells and how does HA contribute to cortical activation and W? At the cellular level, the tonic firing pattern of HA neurons and their low ratio between active/quiet $\mathrm{W}$ suggest that HA neurons contribute to the maintenance of a general brain arousal and consciousness rather than being involved in a specific behavior during $\mathrm{W}$ such as maintaining muscle tone or locomotion. The sustained firing of presumed HA cells during cataplexy in narcoleptic dogs (John et al., 2004) also tends to support this view. Regarding the cortical EEG, we showed that in contrast to $O x^{-1-}$ mice, $H D C^{-1-}$ mice showed reduced EEG contrast between W and SWS and impaired cortical activation such as a deficiency of theta rhythms during W. This EEG impairment would explain the pronounced signs of somnolence in $\mathrm{HDC}^{-1-}$ mice, manifested as shortened sleep latencies and deficiency of $\mathrm{W}$ and exploration faced with behavioral challenges such as lights-off and a new environment (Parmentier et al., 2002). In contrast, $O x^{-1-}$ mice were able to increase $\mathrm{W}$ during their stay in a new environment. The limited decrease in sleep latencies of $O x^{-1-}$ mice compared with that of $H D C^{-l-}$ mice could be explained by less activation of HA neurons due to the lack of the Ox inputs, their major excitatory source (Eriksson et al., 2001; Bayer et al., 2001; Marcus et al., 2001).

These data indicate that unlike Ox neurons, HA neurons are involved in the control of qualitative/cognitive aspects of $\mathrm{W}$ and that their dysfunction leads to somnolence. In support of this, postsynaptic $\mathrm{H} 1$-receptor antagonists impair cognitive performance in humans, whereas activation of HA neurons by H3-receptor inverse agonists enhances cortical fast rhythms, promotes wake duration and improves cognitive performance (Nicholson et al., 1985; Nicholson and Stone, 1986; Ligneau et al., 1998, 2007a,b; Passani et al., 2004; Lin et al., 2008).

\section{Complementary and synergic control of wakefulness by orexin and histamine neurons}

It seems therefore that $\mathrm{Ox}$ and HA neurons have their own and respective role in wake control even though they are located in close proximity and both contribute to promote $\mathrm{W}$ by their similar widespread projections and functional interactions (Eriksson et al., 2001; Huang et al., 2001; Lin et al., 2002). As a brain functional state allowing the performance of crucial behaviors and exploration, $\mathrm{W}$ is also a prerequisite for the socalled "high brain functions" and cognitive activities. Such a vital and complex function could not be ensured by a single neural system. Similarly, the importance of the posterior hypothalamus in wake control cannot be explained by activity of a single neuronal group.

Together, these results suggest that HA and Ox neurons exert a distinct but synergistic and complementary control over W, the amine being mainly responsible for cortical activation (EEG) and cognitive activities during $\mathrm{W}$ and the neuropeptide being more involved in the behavioral arousal during $\mathrm{W}$, including muscle tone, posture, locomotion, food intake, and emotional reactions. The interactions, direct or indirect, between HA and Ox neurons could therefore constitute an important hypothalamic mechanism for the maintenance of $\mathrm{W}$. In terms of their pathological involvement, orexin deficiency is likely the direct cause of narcoleptic episodes (DREMs) and cataplexy, characteristic symptoms of narcolepsy, whereas decreased histaminergic transmission (Nishino et al., 2001; Mignot and Nishino, 2005) could account for the somnolence and excessive daytime sleepiness seen in this disease and other sleep disorders (Parmentier et al., 2002, 2007; Lin et al., 2008).

\section{References}

Anaclet C, Parmentier R, Guidon G, Buda C, Sastre JP, Haas HL, Lin JS (2007) Respective role of histamine and orexin neurons in sleep-wake control. Sleep 30 (Suppl):A24.

Bayer L, Eggermann E, Serafin M, Saint-Mleux B, Machard D, Jones B, Mühlethaler M (2001) Orexins (hypocretins) directly excite tuberomammillary neurons. Eur J Neurosci 14:1571-1575.

Chemelli RM, Willie JT, Sinton CM, Elmquist JK, Scammell T, Lee C, Richardson JA, Williams SC, Xiong Y, Kisanuki Y, Fitch TE, Nakazato M, Hammer RE, Saper CB, Yanagisawa M (1999) Narcolepsy in orexin knockout mice: molecular genetics of sleep regulation. Cell 98:437-451.

de Lecea L, Kilduff TS, Peyron C, Gao X, Foye PE, Danielson PE, Fukuhara C, Battenberg EL, Gautvik VT, Bartlett FS 2nd, Frankel WN, van den Pol AN, Bloom FE, Gautvik KM, Sutcliffe JG (1998) The hypocretins: hypothalamus-specific peptides with neuroexcitatory activity. Proc Natl Acad Sci U S A 95:322-327.

Duxon MS, Stretton J, Starr K, Jones DN, Holland V, Riley G, Jerman J, Brough S, Smart D, Johns A, Chan W, Porter RA, Upton N (2001) Evidence that orexin-A-evoked grooming in the rat is mediated by orexin-1 (OX1) receptors, with downstream 5-HT2C receptor involvement. Psychopharmacology (Berl) 153:203-209.

Eriksson KS, Sergeeva O, Brown RE, Haas HL (2001) Orexin/hypocretin excites the histaminergic neurons of the tuberomammillary nucleus. J Neurosci 21:9273-9279.

España RA, McCormack SL, Mochizuki T, Scammell TE (2007) Running promotes wakefulness and increases cataplexy in orexin knockout mice. Sleep 30:1417-1425.

Franklin K, Paxinos G (1997) The mouse brain in stereotaxic coordinates. San Diego: Academic.

Haas H, Panula P (2003) The role of histamine and the tuberomamillary nucleus in the nervous system. Nat Rev Neurosci 4:121-130.

Haas HL, Sergeeva OA, Selbach O (2008) Histamine in the nervous system. Physiol Rev 88:1183-1241.

Hagan JJ, Leslie RA, Patel S, Evans ML, Wattam TA, Holmes S, Benham CD, Taylor SG, Routledge C, Hemmati P, Munton RP, Ashmeade TE, Shah 
AS, Hatcher JP, Hatcher PD, Jones DN, Smith MI, Piper DC, Hunter AJ, Porter RA, et al. (1999) Orexin A activates locus coeruleus cell firing and increases arousal in the rat. Proc Natl Acad Sci U S A 96:10911-10916.

Huang ZL, Qu WM, Li WD, Mochizuki T, Eguchi N, Watanabe T, Urade Y, Hayaishi O (2001) Arousal effect of orexin A depends on activation of the histaminergic system. Proc Natl Acad Sci U S A 98:9965-9970.

John J, Wu MF, Boehmer LN, Siegel JM (2004) Cataplexy-active neurons in the hypothalamus: implications for the role of histamine in sleep and waking behavior. Neuron 42:619-634.

Jones DN, Gartlon J, Parker F, Taylor SG, Routledge C, Hemmati P, Munton RP, Ashmeade TE, Hatcher JP, Johns A, Porter RA, Hagan JJ, Hunter AJ, Upton N (2001) Effects of centrally administered orexin-B and orexin-A: a role for orexin-1 receptors in orexin-B-induced hyperactivity. Psychopharmacology (Berl) 153:210-218.

Lee MG, Hassani OK, Jones BE (2005) Discharge of identified orexin/hypocretin neurons across the sleep-waking cycle. J Neurosci 25:6716-6720.

Ligneau X, Lin J, Vanni-Mercier G, Jouvet M, Muir JL, Ganellin CR, Stark H, Elz S, Schunack W, Schwartz J (1998) Neurochemical and behavioral effects of ciproxifan, a potent histamine H3-receptor antagonist. J Pharmacol Exp Ther 287:658-666.

Ligneau X, Perrin D, Landais L, Camelin JC, Calmels TP, Berrebi-Bertrand I, Lecomte JM, Parmentier R, Anaclet C, Lin JS, Bertaina-Anglade V, la Rochelle CD, d'Aniello F, Rouleau A, Gbahou F, Arrang JM, Ganellin CR, Stark H, Schunack W, Schwartz JC (2007a) BF2.649 [1-\{3-[3-(4chlorophenyl)propoxy] propyl\}piperidine, hydrochloride], a nonimidazole inverse agonist/antagonist at the human histamine $\mathrm{H} 3$ receptor: preclinical pharmacology. J Pharmacol Exp Ther 320:365-375.

Ligneau X, Landais L, Perrin D, Piriou J, Uguen M, Denis E, Robert P, Parmentier R, Anaclet C, Lin JS, Burban A, Arrang JM, Schwartz JC (2007b) Brain histamine and schizophrenia: potential therapeutic applications of H3-receptor inverse agonists studied with BF2.649. Biochem Pharmacol 73:1215-1224.

Lin JS (2000) Brain structures and mechanisms involved in the control of cortical activation and wakefulness, with emphasis on the posterior hypothalamus and histaminergic neurons. Sleep Med Rev 4:471-503.

Lin JS, Sakai K, Jouvet M (1988) Evidence for histaminergic arousal mechanisms in the hypothalamus of cat. Neuropharmacology 27:111-122.

Lin JS, Sakai K, Vanni-Mercier G, Jouvet M (1989) A critical role of the posterior hypothalamus in the mechanisms of wakefulness determined by microinjection of muscimol in freely moving cats. Brain Res 479:225-240.

Lin JS, Hou Y, Sakai K, Jouvet M (1996) Histaminergic descending inputs to the mesopontine tegmentum and their role in the control of cortical activation and wakefulness in the cat. J Neurosci 16:1523-1537.

Lin JS, Dauvilliers Y, Arnulf I, Bastuji H, Anaclet C, Parmentier R, Kocher L, Yanagisawa M, Lehert P, Ligneau X, Perrin D, Robert P, Roux M, Lecomte JM, Schwartz JC (2008) An inverse agonist of the histamine H(3) receptor improves wakefulness in narcolepsy: studies in orexin ${ }^{-1-}$ mice and patients. Neurobiol Dis 30:74-83.

Lin L, Faraco J, Li R, Kadotani H, Rogers W, Lin X, Qiu X, de Jong PJ, Nishino S, Mignot E (1999) The sleep disorder canine narcolepsy is caused by a mutation in the hypocretin (orexin) receptor 2 gene. Cell 98:365-376.

Lin L, Wisor J, Shiba T, Taheri S, Yanai K, Wurts S, Lin X, Vitaterna M, Takahashi J, Lovenberg TW, Koehl M, Uhl G, Nishino S, Mignot E (2002) Measurement of hypocretin/orexin content in the mouse brain using an enzyme immunoassay: the effect of circadian time, age and genetic background. Peptides 23:2203-2211.

Marcus JN, Aschkenasi CJ, Lee CE, Chemelli RM, Saper CB, Yanagisawa M, Elmquist JK (2001) Differential expression of orexin receptors 1 and 2 in the rat brain. J Comp Neurol 435:6-25.

Martins PJ, D’Almeida V, Pedrazzoli M, Lin L, Mignot E, Tufik S (2004) Increased hypocretin-1 (orexin-a) levels in cerebrospinal fluid of rats after short-term forced activity. Regul Pept 117:155-158.

McCormick DA (1992) Neurotransmitter actions in the thalamus and cerebral cortex and their role in neuromodulation of thalamocortical activity. Prog Neurobiol 39:337-388.

MignotE (2005) Narcolepsy: pharmacology, pathophysiology and genetics. In: Principles and practice of sleep medicine (Kryger MH, Roth T, Dement WC, eds), pp 761-779. Philadelphia: Elsevier Saunders.
Mignot E, Nishino S (2005) Emerging therapies in narcolepsy-cataplexy. Sleep 28:754-763.

Mileykovskiy BY, Kiyashchenko LI, Siegel JM (2005) Behavioral correlates of activity in identified hypocretin/orexin neurons. Neuron 46:787-798.

Modirrousta M, Mainville L, Jones BE (2005) Orexin and MCH neurons express c-Fos differently after sleep deprivation vs. recovery and bear different adrenergic receptors. Eur J Neurosci 21:2807-2816.

Monti JM (1993) Involvement of histamine in the control of the waking state. Life Sci 53:1331-1338.

Moruzzi G (1972) The sleep-waking cycle. Ergeb Physiol 64:1-165.

Nicholson AN, Stone BM (1986) Antihistamines: impaired performance and the tendency to sleep. Eur J Clin Pharmacol 30:27-32.

Nicholson AN, Pascoe PA, Stone BM (1985) Histaminergic systems and sleep. Studies in man with $\mathrm{H} 1$ and $\mathrm{H} 2$ antagonists. Neuropharmacology 24:245-250.

Nishino S, Fujiki N, Ripley B, Sakurai E, Kato M, Watanabe T, Mignot E, Yanai K (2001) Decreased brain histamine content in hypocretin/orexin receptor-2 mutated narcoleptic dogs. Neurosci Lett 313:125-128.

Ohtsu H, Tanaka S, Terui T, Hori Y, Makabe-Kobayashi Y, Pejler G, Tchougounova E, Hellman L, Gertsenstein M, Hirasawa N, Sakurai E, Buzás E, Kovács P, Csaba G, Kittel A, Okada M, Hara M, Mar L, Numayama-Tsuruta K, Ishigaki-Suzuki S, et al. (2001) Mice lacking histidine decarboxylase exhibit abnormal mast cells. FEBS Lett 502:53-56.

Parmentier R, Ohtsu H, Djebbara-Hannas Z, Valatx JL, Watanabe T, Lin JS (2002) Anatomical, physiological, and pharmacological characteristics of histidine decarboxylase knock-out mice: evidence for the role of brain histamine in behavioral and sleep-wake control. J Neurosci 22:76957711.

Parmentier R, Anaclet C, Guhennec C, Brousseau E, Bricout D, Giboulot T, Bozyczko-Coyne D, Spiegel K, Ohtsu H, Williams M, Lin JS (2007) The brain $\mathrm{H} 3$-receptor as a novel therapeutic target for vigilance and sleepwake disorders. Biochem Pharmacol 73:1157-1171.

Passani MB, Lin JS, Hancock A, Crochet S, Blandina P (2004) The histamine $\mathrm{H} 3$ receptor as a novel therapeutic target for cognitive and sleep disorders. Trends Pharmacol Sci 25:618-625.

Sakai K, Mansari M, Lin JS, Zhang JG, Vanni-Mercier G (1990) The posterior hypothalamus in the regulation of wakefulness and paradoxical sleep. In: The diphencephalon and sleep (Mancia M, Marini G, eds), pp 171198. New York: Raven.

Sakurai T (2007) The neural circuit of orexin (hypocretin): maintaining sleep and wakefulness. Nat Rev Neurosci 8:171-181.

Sakurai T, Amemiya A, Ishii M, Matsuzaki I, Chemelli RM, Tanaka H, Williams SC, Richardson JA, Kozlowski GP, Wilson S, Arch JR, Buckingham RE, Haynes AC, Carr SA, Annan RS, McNulty DE, Liu WS, Terrett JA, Elshourbagy NA, Bergsma DJ, et al. (1998) Orexins and orexin receptors: a family of hypothalamic neuropeptides and G protein-coupled receptors that regulate feeding behavior. Cell 92:573-585.

Sallanon M, Sakai K, Buda C, Puymartin M, Jouvet M (1988) Increase of paradoxical sleep induced by microinjections of ibotenic acid into the ventrolateral part of the posterior hypothalamus in the cat. Arch Ital Biol 126:87-97.

Sallanon M, Denoyer M, Kitahama K, Aubert C, Gay N, Jouvet M (1989) Long-lasting insomnia induced by preoptic neuron lesions and its transient reversal by muscimol injection into the posterior hypothalamus in the cat. Neuroscience 32:669-683.

Saper CB (2000) Hypothalamic connections with the cerebral cortex. Prog Brain Res 126:39-48.

Sastre JP, Buda C, Lin JS, Jouvet M (2000) Differential c-fos expression in the rhinencephalon and striatum after enhanced sleep-wake states in the cat. Eur J Neurosci 12:1397-1410.

Schwartz JC, Arrang JM, Garbarg M, Pollard H, Ruat M (1991) Histaminergic transmission in the mammalian brain. Physiol Rev 71:1-51.

Smart D, Sabido-David C, Brough SJ, Jewitt F, Johns A, Porter RA, Jerman JC (2001) SB-334867-A: the first selective orexin-1 receptor antagonist. Br J Pharmacol 132:1179-1182.

Soffin EM, Evans ML, Gill CH, Harries MH, Benham CD, Davies CH (2002) SB-334867-A antagonises orexin mediated excitation in the locus coeruleus. Neuropharmacology 42:127-133.

Steininger TL, Alam MN, Gong H, Szymusiak R, McGinty D (1999) Sleepwaking discharge of neurons in the posterior lateral hypothalamus of the albino rat. Brain Res 840:138-147.

Takahashi K, Lin JS, Sakai K (2006) Neuronal activity of histaminergic tu- 
beromammillary neurons during wake-sleep states in the mouse. J Neurosci 26:10292-10298.

Takahashi K, Lin JS, Sakai K (2008) Neuronal activity of orexin and nonorexin waking-active neurons during wake-sleep states in the mouse. Neuroscience 153:860-870.

Takahashi K, Lin JS, Sakai K (2009) Characterization and mapping of sleepwaking specific neurons in the basal forebrain and preoptic hypothalamus in mice. Neuroscience 161:269-292.

Torterolo P, Yamuy J, Sampogna S, Morales FR, Chase MH, (2001) Hypothalamic neurons that contain hypocretin (orexin) express c-fos during active wakefulness and carbachol-induced active sleep. Sleep Res Online 4:25-32.

Valatx JL (1971) [Long-term recording of cerebral, muscular and ocular electric activities in mice]. C R Seances Soc Biol Fil 165:112-115.
Valatx JL, Bugat R (1974) [Genetic factors as determinants of the waking-sleep cycle in the mouse (author's translation)]. Brain Res 69:315-330.

Valdés JL, Farías P, Ocampo-Garcés A, Cortés N, Serón-Ferré M, Torrealba F (2005) Arousal and differential Fos expression in histaminergic neurons of the ascending arousal system during a feeding-related motivated behaviour. Eur J Neurosci 21:1931-1942.

Vanni-Mercier G, Gigout S, Debilly G, Lin JS (2003) Waking selective neurons in the posterior hypothalamus and their response to histamine $\mathrm{H} 3$ receptor ligands: an electrophysiological study in freely moving cats. Behav Brain Res 144:227-241.

von Economo C (1926) Die Pathologie des Schlafes. In: Handbuch der normalen und pathologischen Physiologie (von Bethe A, von Bergmann G, Embden G, Ellinger A, Eds), Vol 17, pp 591-610. Springer: Berlin. 